\title{
Diagenesis versus hydrothermalism and fluid-rock interaction within the Tuscan Nappe of the Monte Amiata $\mathrm{CO}_{2}$-rich geothermal area (Italy)
}

\author{
M. GASPARRINI ${ }^{1}$, G. RUGGIERI ${ }^{2}$ AND A. BROGI ${ }^{3}$ \\ ${ }^{1}$ IFP Energies nouvelles, Rueil-Malmaison, France; ${ }^{2}$ CNR - Istituto di Geoscienze e Georisorse, Florence, Italy; ${ }^{3}$ Dipartimento \\ di Scienze delle Terre e Geoambientali, Università di Bari Aldo Moro, Bari, Italy
}

\begin{abstract}
In southern Tuscany (central Italy), deep to shallow geothermal systems were active since the Pleistocene and comprise fluids carrying variable amounts of $\mathrm{CO}_{2}$. The Monte Amiata geothermal fields include two main reservoirs: a deep one located in the Palaeozoic metamorphic succession (1300-3000 m deep) belonging to the Tuscan metamorphic 'basement' and a shallow one hosted in the Mesozoic sedimentary succession (500-1000 m deep) belonging to the Tuscan Nappe. Multiple sets of calcite veins were investigated in some outcrops of the Tuscan Nappe succession exposed in the Monte Amiata area and surroundings. Two main fluid systems were characterized: the former related to combined diagenetic syn-tectonic processes from highly saline fluids after interaction with the Late Triassic evaporites (Burano Fm) and the latter related to a fossil geothermal system, Pleistocene in age, fed by low-salinity meteoric fluids, carrying $\mathrm{CO}_{2}$, radiogenic $\mathrm{Sr}$ and heavy $\mathrm{O}$ isotopes after interaction with the subsurface rocks. Comparison with the present-day hydrothermal fluids allowed to sketch the thermal evolution of the system from past to present. Geochemical data proved that portions of the vein-host rocks were reset after interaction with $\mathrm{CO}_{2}$-rich fluids circulating in the past. Consequently, textural and mineralogical changes are expected to have occurred with respect to the undisturbed rock masses. Understanding these modifications, their location and extension, is a prerequisite to construct (i) geochemical models addressed to the comprehension of the diagenesis induced in sediments after long-term $\mathrm{CO}_{2}$ storage; and (ii) geological models applied to the prediction of rock heterogeneity distribution within the upper reservoirs, characterizing the shallow (500-1500 m) geothermal systems of southern Tuscany.
\end{abstract}

Key words: $\mathrm{CO}_{2}$, fluid inclusions, geothermics, isotopes, southern Tuscany

Received 31 August 2012; accepted 12 February 2013

Corresponding author: Marta Gasparrini, IFP Energies nouvelles, Department of Sedimentology-Stratigraphy, R133, 1-4 Avenue de Bois-Préau, 92852 Rueil-Malmaison, France.

E-mail: marta.gasparrini@ifpen.fr. Tel: +33 0147525429. Fax: +33 0147527126.

Geofluids (2013) 13, 159-179

\section{INTRODUCTION}

Successful $\mathrm{CO}_{2}$ geological storage requires the understanding of the physical and chemical processes that may occur after injection. Under the assumed P-T storage conditions, $\mathrm{CO}_{2}$ is very soluble in water and produces acidic solutions (Rochelle et al. 2004; Kervevan et al. 2005) in thermodynamic disequilibrium with the host rocks, which in turn may undergo modification of their mineralogical, geochemical and textural features. Consequently, the effect of the $\mathrm{CO}_{2}$ dissolved in pore fluids on the host lithologies has becoming, in the last decade, a fertile field of investigation (e.g. Baines \& Worden 2004; Brosse et al. 2005;
Czernichowski-Lauriol et al. 2006; Pauwels et al. 2007 and references therein).

The geochemical modelling of $\mathrm{CO}_{2}$-water-mineral interactions is a tool to estimate the reservoir-quality evolution induced by $\mathrm{CO}_{2}$ anthropogenic injections. However, models developed independently from the observation of short- and long-term diagenetic modifications induced by reaction with $\mathrm{CO}_{2}$-charged fluids may lead to false assumptions. The prediction of dawsonite precipitation ( $\mathrm{Xu}$ et al. 2003; Johnson et al. 2004) as a by-product of $\mathrm{CO}_{2}$-water -rock interaction, a mineral phase only locally recorded in $\mathrm{CO}_{2}$ natural systems (Worden 2006; Wilkinson et al. 2009; Hellevang et al. 2011), underlines the need to cali- 
brate models with analogues. The use of samples from natural $\mathrm{CO}_{2}$ accumulations (e.g. Pearce et al. 2003; Baines \& Worden 2004; IEA GHG 2005; Lu 2009), the monitoring of $\mathrm{CO}_{2}$-water-rock reactions in laboratory experiments (e.g. Wigand et al. 2008; Luquot \& Gouze 2009; Sterpenich et al. 2009) as well as at sites of recent injection (e.g. Emberley et al. 2005; Kharaka et al. 2006; Assayag et al. 2009) may therefore assist in constraining modelling.

In such a context, the understanding of long-term impact of $\mathrm{CO}_{2}$-rich fluids on mineralogical and geochemical features of sedimentary rocks from natural $\mathrm{CO}_{2}$ accumulations has been approached by several authors (Gaus et al. 2004; Watson et al. 2004a,b; Beitler et al. 2005; Haszeldine et al. 2005; May 2005; Moore et al. 2005; Schacht 2008; Lu et al. 2009; Wilkinson et al. 2009; Armitage et al. 2010), although they mainly treated siliciclastic reservoirs (sandstones) or cap rocks (claystones). Conversely, the diagenesis induced on carbonate-dominated successions by long-term reactions with $\mathrm{CO}_{2}$-rich fluids is less well documented. Pure carbonate reservoirs may be inert to $\mathrm{CO}_{2}$-rich fluids, although the most obviously predicted phenomena are dissolution, porosity enhancement and inhibition of carbonate mineral growth (e.g. Baines \& Worden 2004; Watson et al. 2004a; Czernichowski-Lauriol et al. 2006). The occurrence of the two different behaviours (unreactive versus reactive) depends on the openness of the system and, for open systems, on the fluid advective flow rate. Further complexity is added by the presence of clastic impurities in carbonate rocks, which could allow alumino-silicates dissolution and precipitation of Fe-rich carbonates.

Numerous shallow depth geothermal systems exist on the Earth and are locally exploited for electric power production (e.g. Henley \& Ellis 1983; Barbier 2002). Because of the common interconnection with deep origin fluids, these superficial geothermal systems commonly carry abundant $\mathrm{CO}_{2}$ (e.g. Henley \& Ellis 1983; Armannsson 2003; Chiodini et al. 2008). The well-known geothermal systems from southern Tuscany (Italy) display a large variation in $\mathrm{CO}_{2}$ concentrations (Baldi et al. 1993; Gianelli et al. 1997a); among the others, the geothermal fields of Piancastagnaio and Bagnore, close to the Monte Amiata (Fig. 1), in southern Tuscany (e.g. Gianelli et al. 1988; Brogi 2008). Accurate characterization of the past fluids circulating into these systems was achieved mainly for the deeper and hotter metamorphic reservoirs (Belkin et al. 1985; Ruggieri et al. 2004; Giolito 2005) because of their major interest in geothermal exploration. The shallower reservoirs $(500-1000 \mathrm{~m})$, mainly hosted by the sedimentary succession of the Tuscan Nappe (Calamai et al. 1970; Bertini et al. 1995; Barelli et al. 2010), were less studied (and exploited), and information about the evolution of the system from diagenesis to the later hydrothermalism is scarce.
On the north-eastern side of the Monte Amiata volcano (Ferrari et al. 1996), near the locality of Bagni San Filippo, the Tuscan Nappe succession is broadly exposed in the Poggio Zoccolino area (Fig. 1; Calamai et al. 1970; Brogi 2004). This is at present the site of a shallow $\mathrm{CO}_{2}$-charged hydrothermal system, with warm springs discharging on surface (Chiodini et al. 1995; Minissale et al. 1997; Frondini et al. 2009). Here, calcite veins are hosted within the Early Jurassic and dominantly carbonatic Tuscan Nappe succession, close to the contact with the overlying Ligurian Units (Brogi 2004; Pandeli et al. 2005). The veins were characterized by means of conventional and cathodoluminescence (CL) petrography, oxygen $(\mathrm{O})$, carbon $(\mathrm{C})$ and strontium $(\mathrm{Sr})$ isotopes, trace elements, as well as microthermometry and Raman spectroscopy on fluid inclusions (FIs). Petrographic and geochemical characterization was accomplished also for the different vein-host lithologies.

The aim of the present contribution is twofold: (i) to constrain the relative timing of vein formation, as well as the temperature and composition of the parent fluids in order to relate the vein origin with the geological evolution of the area and in particular with the migration events of $\mathrm{CO}_{2}$-rich fluids. This allowed to sketch the evolution of the fluid system from past to present by building a fracture paragenesis and to discriminate the events of calcite mineralization related to the fossil hydrothermal system of Bagni San Filippo; and (ii) to investigate the geochemical modifications induced on the vein host rocks having interacted with ancient $\mathrm{CO}_{2}$-rich fluids. This revealed some interesting features for the understanding of both the geochemical behaviour of carbonate-dominated sediments having reacted with such $\mathrm{CO}_{2}$-rich fluids and the heterogeneity distribution and compartmentalization within the shallower reservoirs of the Monte Amiata geothermal system.

\section{GEOLOGICAL SETTING}

The structural and stratigraphic setting of southern Tuscany is related to the evolution of the inner northern Apennines, a Tertiary (Late Cretaceous-Early Miocene) belt resulting from the collision between the Adria microplate and the European plate (e.g. Molli 2008). After the emplacement of the tectonic units, extensional tectonics (Carmignani et al. 1994; Brogi 2008) and coeval magmatism (Dini et al. 2005) affected the inner northern Apennines (northern Tyrrhenian Sea and Tuscany) since the Early-Middle Miocene (Brunet et al. 2000) and gave rise to widespread hydrothermal circulation.

In the Monte Amiata area (Fig. 1), the tectonic pile is characterized by different tectono-stratigraphic units. They consist of, from top to bottom (Fig. 2):

(1) The Monte Amiata volcanic complex, given by dacitic, rhyodacitic and olivine-latitic rocks (300-190 ka; Ferrari et al. 1996 and references therein). 


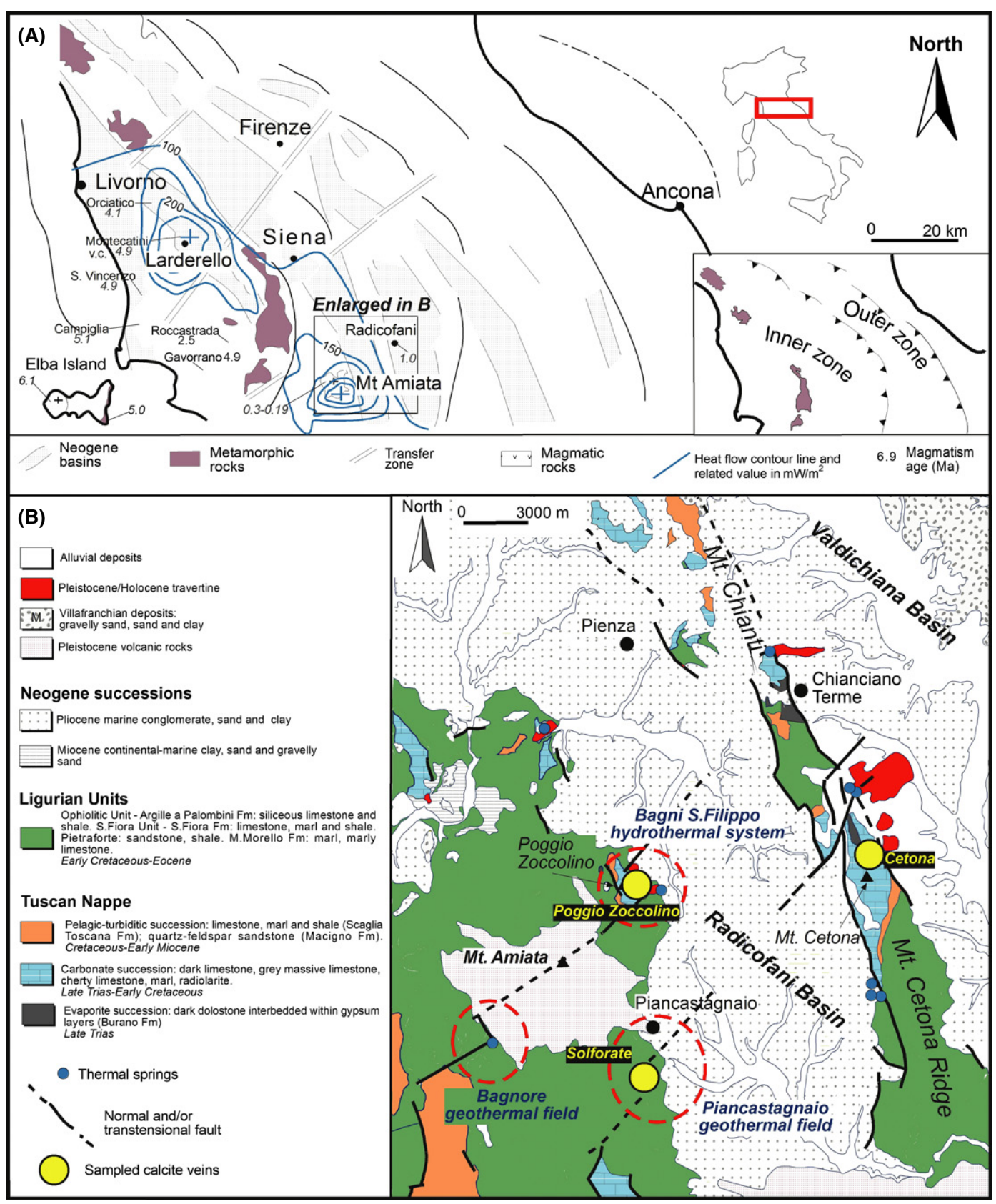

Fig. 1. (A) Structural sketch map of southern Tuscany with regional heat flow contours (interval $50 \mathrm{~mW} \mathrm{~m}^{-2}$ ). The plus signs show the Larderello and Monte Amiata geothermal fields, where heat flow reaches values up to 1000 and $600 \mathrm{~mW} \mathrm{~m}^{-2}$, respectively (redrawn from Baldi et al. 1993). (B) Geological sketch map of the Mt Chianti-Mt Cetona Range and Monte Amiata, where rock sampling was performed (modified after Brogi et al. 2011).

(2) Neogene and Quaternary deposits. They consist of Middle Miocene-Quaternary continental and marine sediments filling the tectonic depressions (e.g. the Radicofani Basin, Fig. 1) and Quaternary travertines;

(3) The Ligurian and Subligurian Units. The Ligurian Units (S. Fiora Unit: Early Cretaceous-Eocene; and Ophiolitic Unit: Middle Jurassic-Early Cretaceous) are composed of remnants of the Jurassic oceanic basement and its pelagic sedimentary cover, whereas the Subligurian Unit (Eocene-Oligocene) is composed of a pelagic succession deposited on a palaeogeographical domain interposed between the Ligurian Domain and the Tuscan Domain.

(4) The Tuscan Nappe. It is related to part of the Late Triassic-Early Miocene sedimentary cover of the Adria continental palaeomargin. Its stratigraphic succession is made of (from bottom to top) evaporitic (Late Triassic, TNl in Fig. 2), carbonate (Late Triassic-Early Cretaceous, TN2 in Fig. 2) and pelagic-turbiditic (Cretaceous-Early Miocene, TN3 in Fig. 2) successions. 


\section{Monte Amiata volcano}

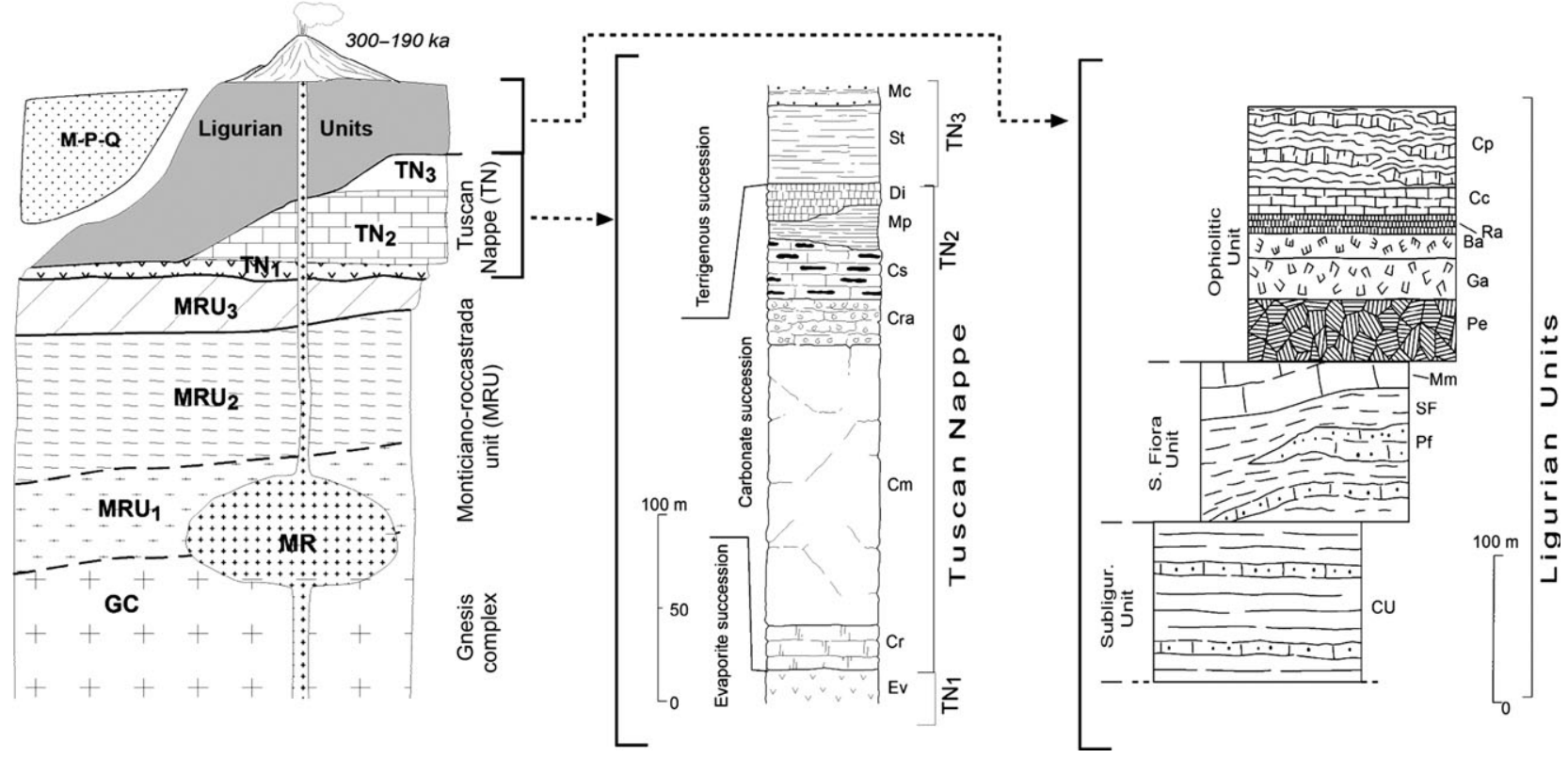

Fig. 2. Tectono-stratigraphic units in the Monte Amiata area (modified after Batini et al. 2003); M-P-Q: Miocene, Pliocene and Quaternary sediments; MR - magmatic rocks; Tuscan Nappe (TN): TN3 - Early Miocene-Cretaceous clayey-turbiditic succession; TN2 - Cretaceous-Rhaetian carbonate succession, TN1 - Late Triassic evaporite succession; Monticiano-Roccastrada Unit (MRU): MRU3 - Triassic Verrucano Group; MRU2 - Palaeozoic Phyllite-Quartzite Group; MRU1 - Palaeozoic Micaschist Group; GC - Palaeozoic Gneiss Complex. Tuscan Nappe: Ev - Late Triassic evaporites (Burano Fm) composed of an alternation of dolostone and dolomitic limestone and gypsum layers often brecciated; $\mathrm{Cr}$ - Late Triassic carbonate succession (Calcari a Rhaetavicula contorta Fm) composed of Rhaetian dark limestone interbedded with decimetre thick marl and marly limestone; Cm - Early Jurassic massive grey limestone (Calcare Massiccio Fm); Cra - Early Jurassic red nodular limestone and marly limestone and grey cherty limestone (Calcare Rosso Ammonitico Fm); Mp - Middle Jurassic marl and marly limestone (Marne a Posidonia Fm); Di - Late Jurassic radiolarite (Diaspri Fm); Sc - Cretaceous-Oligocene shale, marl, limestone, calcarenite and calcirudite (Scaglia Toscana Fm); Ma - Late Oligocene-Early Miocene sandstone and shale (Macigno Fm). Ligurian Units: CU - Eocene-Oligocene limestone and shale (Canetolo Fm); Sf - Cretaceous limestone, marl and shale (S. Fiora Fm); Pf - Cretaceous sandstone (Pietraforte Fm); Mm - PalaeoceneEocene marl and limestone (Monte Morello Fm); Pe - Jurassic peridotite; Ga - Jurassic grabbro; Ba - Jurassic basalt; Ra - Late Jurassic radiolarites (Diaspri Fm); Cc - Early Cretaceous siliceous limestone (Calcari a Calpionella Fm); Cp - Early Cretaceous shale and siliceous limestone (Calcari a Palombini).

The Tuscan Nappe was detached from its substratum along the Triassic evaporite horizon (TNl) and was thrusted over the outer palaeogeographical domains (Umbria-Marchigian Domain) during the Late Oligocene-Early Miocene contraction.

(5) The Tuscan Metamorphic 'basement' has been only encountered by deep boreholes (Elter \& Pandeli 1991) and has been referred to the Monticiano-Roccastrada Unit (MRU in Fig. 2). It has been described as a lowgrade metamorphic succession made of Triassic continental metapelites, metasandstones and metaconglomerates (Verrucano Group, MRU3 in Fig. 2) and Palaeozoic graphitic phyllites and metasandstones (MRU2 in Fig. 2). The occurrence of the Micaschist Group (MRUl in Fig. 2) and the Gneiss Complex (GC in Fig. 2) at depth has been documented by xenoliths in the Quaternary lavas.

The occurrence of a geothermal anomaly characterizing the Monte Amiata volcanic area and surroundings (Batini et al. 2003) has been referred to the presence of a cooling granitoid at about $6-7 \mathrm{~km}$ below sea level and metaso- matic fluids (Gianelli et al. 1988, 1997b). The emplacement of such a magmatic body, as well as the volcanic eruptions, were driven by a main SW-NE trending shear zone consisting of en-echelon fault segments with transtensional movements and related releasing stepover zones (Brogi et al. 2010). Geothermal manifestations at Monte Amiata possibly started in the Pleistocene (Batini et al. 2003) and produced epithermal Sb-Hg mineralization (Lattanzi 1999; Brogi et al. 2011), both concentrated along the main fault segments and the linkage zones (Brogi et al. 2010).

The Tuscan Nappe stratigraphic succession is well exposed at Poggio Zoccolino and Monte Cetona (Fig. 1), located on the north-eastern side of the Monte Amiata volcano and in the eastern shoulder of the Neogene Radicofani Basin, respectively (Fig. 1). Poggio Zoccolino falls within the Monte Amiata geothermal anomaly and is characterized by the long-living geothermal system of Bagni San Filippo, as indicated by the presence of an exhumed $\mathrm{Hg}$ mineralization, Pleistocene in age, and by the occurrence of thermal springs and gas (mainly $\mathrm{CO}_{2}$ ) vents. In contrast, 

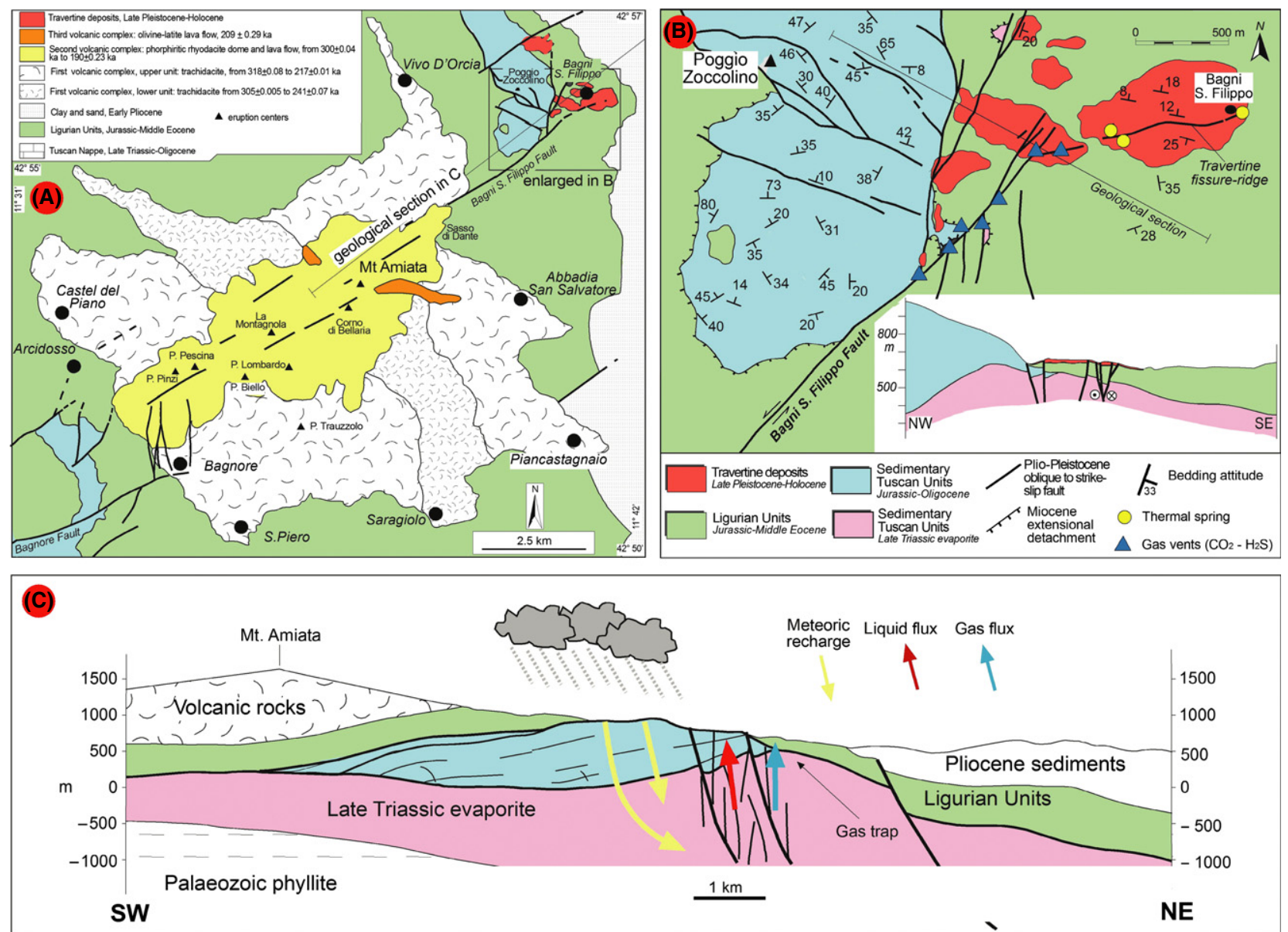

Fig. 3. (A) Simplified geological map of the Monte Amiata area (Brogi et al. 2010). Bagnore and Piancastagnaio are the sites of geothermal energy exploitation. (B) Detailed sketch map and cross-section of the Poggio Zoccolino area (modified from Brogi et al. 2010); sampled Tuscan Nappe outcrops were close to thermal springs (yellow dots) and cold $\mathrm{CO}_{2}$ emissions (blue triangles). (C) Geological section (trace shown in A) illustrating the main elements of the present shallow hydrothermal systems (e.g. Bagni San Filippo) fed by meteoric recharge, heated and enriched in $\mathrm{CO}_{2}$ at depth (modified from Chiodini et al. 1995; Brogi et al. 2010).

the Monte Cetona is located far from the geothermal anomaly; here, the outcropping Tuscan Nappe succession never interacted with hydrothermal fluids. In both areas, the Tuscan Nappe evaporite and overlying carbonate succession (see stratigraphy in Fig. 2) are extensively exposed (Passerini 1964; Calamai et al. 1970). They were deformed during the precollisional (syn-diagenetic brittle-brittle/ductile deformation), collisional and postcollisional tectonics and recorded mainly thrusting and folding events followed by extensional structures (Brogi 2008).

\section{GEOTHERMAL SYSTEMS AND $\mathrm{CO}_{2}$ ORIGIN}

After the first exploration programme developed in the 1950s and 1960s the Bagnore and Piancastagnaio geothermal fields (Figs $\mathrm{l}$ and $3 \mathrm{~A}$ ) produced from the shallow carbonate-evaporite reservoir at depths of 500-1000 m. The second exploration programme developed in the 1970 in the metamorphic units at depths of 1300-3000 m. Both reservoirs are water dominated under hydrostatic pressure conditions and temperatures around $150-210^{\circ} \mathrm{C}$ (upper reservoir) and $300-360^{\circ} \mathrm{C}$ (lower reservoir; Bertini et al. 1995; Barelli et al. 2010). The dominant gas phase is $\mathrm{CO}_{2}$. The geothermal gradient is between 80 and $150^{\circ} \mathrm{C} /$ $\mathrm{km}$ with local peaks in Bagnore and Piancastagnaio fields (heat flow up to $600 \mathrm{~mW} \mathrm{~m}^{-2}$; Baldi et al. 1993).

A regional aquifer is located in the Mesozoic carbonate succession of the Tuscan Nappe, which is overlain by the low-permeability cover represented by the shale, marl and sandstone belonging to the Ligurian and Subligurian Units, and comprises discontinuous recharge areas corresponding to the carbonate-evaporite outcropping formations. North-east of the Amiata volcano is the shallow hydrothermal system of Bagni San Filippo (Figs 1 and 3), hosted by the evaporite-carbonate Tuscan Nappe rocks and capped by the Ligurian siliciclastics, which crop out at Poggio Zoccolino (Figs 1 and 3). This system is characterized by equilibrium temperatures of $60-80^{\circ} \mathrm{C}, \mathrm{pCO}_{2}$ of 

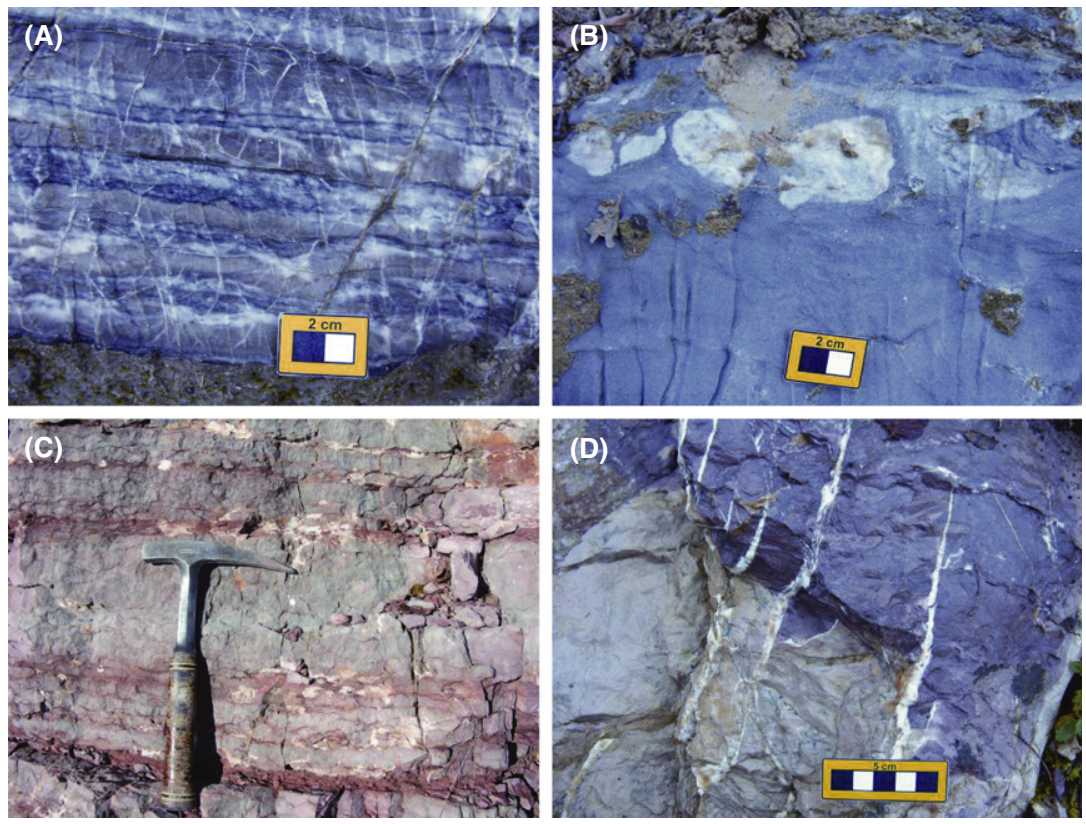

Fig. 4. Field photographs illustrating the main sampled formations and hosted calcite veins. (A) Dolomitic evaporites of the Burano Fm from Poggio Zoccolino. (B) Chicken wire structures of anhydrite nodules in Burano Fm dolomitic evaporites from Poggio Zoccolino. (C) Grey nodular limestones interbedded with reddish clays (Calcare Rosso Ammonitico Fm) from Monte Cetona. (D) Syn-tectonic calcite veins (en-echelon arrangements) in reddish nodular limestone (Calcare Rosso Ammonitico Fm) from Poggio Zoccolino.

10 bar (Chiodini et al. 1995; Donnini et al. 2007) and by the highest groundwater $\mathrm{pCO}_{2}$ of the region $(0.0235$ 0.6946 bar; Frondini et al. 2009). The presence of the hydrothermal system is expressed at surface by warm springs $\left(42-52^{\circ} \mathrm{C}\right.$; Minissale et al. 1997; Frondini et al. 2009) discharging from the Tuscan Nappe reservoirs. The thermal springs that are fed by Cl-poor fluids of meteoric recharge and heated at depth in response of the local thermal anomaly (Fig. 3; Minissale et al. 1997; Minissale 2004) emerge through fractures and are representative of the $\mathrm{CO}_{2}$-rich hydrothermal system at depth (Chiodini et al. 1995). Gas emissions at surface, dominated by $\mathrm{CO}_{2}$ (>90 vol\%; Minissale et al. 1997; Donnini et al. 2007), leak from the same system (Fig. 3; Chiodini et al. 1995; Donnini et al. 2007; Frondini et al. 2009).

The source of $\mathrm{CO}_{2}$ for the Amiata area is still debated. The gases at Bagni San Filippo display $\mathrm{CO}_{2}$ as main component followed by $\mathrm{N}_{2}, \mathrm{H}_{2} \mathrm{~S}, \mathrm{CH}_{4}, \mathrm{Ar}, \mathrm{H}_{2}, \mathrm{He}$ and $\mathrm{CO}$. They are interpreted as derived from a mantle source contaminated by a $\mathrm{N}_{2}$-rich crustal component (Frondini et al. 2009). Even if a contaminated mantle is the main source of $\mathrm{CO}_{2}$-rich gases in central Italy (Chiodini et al. 2004), a variable contribution of metamorphic $\mathrm{CO}_{2}$ is deduced from $\mathrm{T} /$ $\mathrm{pCO}_{2}$ ratios for the Monte Amiata geothermal area. Regardless of the origin, the gas, possibly composed of a mixture of contaminated mantle and metamorphic $\mathrm{CO}_{2}$, enters the deep reservoirs of the area and is dissolved in the geothermal fluid. The latter carries the dissolved gas towards the shallow geothermal reservoirs where it is trapped (Fig. 3). Locally, a free gas phase may separate from the fluid and moves towards the surface (Frondini et al. 2009).

\section{SAMPLED MATERIAL \& METHODS}

Rock samples were collected at Poggio Zoccolino, Cetona and Solforate (Figs 4 and 5). Specimens from the Tuscan Nappe succession close to the Bagni San Filippo hydrothermal area (Poggio Zoccolino in Fig. 1) were sampled from the Burano Fm up to the Marne a Posidonia Fm (Fig. 2). Samples of vein mineralization hosted by the different outcropping lithologies were sampled as well. Rock specimens of the Jurassic Tuscan Nappe succession away from any past and present hydrothermal activity were sampled also from the continuous Monte Cetona succession (Cetona in Fig. 1) from the Burano Fm up to the Marne a Posidonia Fm (Fig. 2). Cross-cutting calcite veins occurred also in outcrops of the relatively impermeable cap rocks of the Ligurian Units on the south-eastern side of the Monte Amiata at the Solforate Mine (Solforate in Fig. 1) and were sampled for comparison (Fig. 5D).

About 50 thin sections (30-35 $\mu \mathrm{m}$ thick) were prepared for conventional and cathodoluminescence (CL) microscopy. From the coarser crystalline samples, double-polished thick sections (100-120 $\mu \mathrm{m}$ thick) were prepared for fluid inclusion (FI) petrography and microthermometry. Thinsection petrography was carried out on a Nikon ECLIPSE LV100 POL. The device used for cold CL is a Technosyn 8200 Mark II (OPEA, France). 

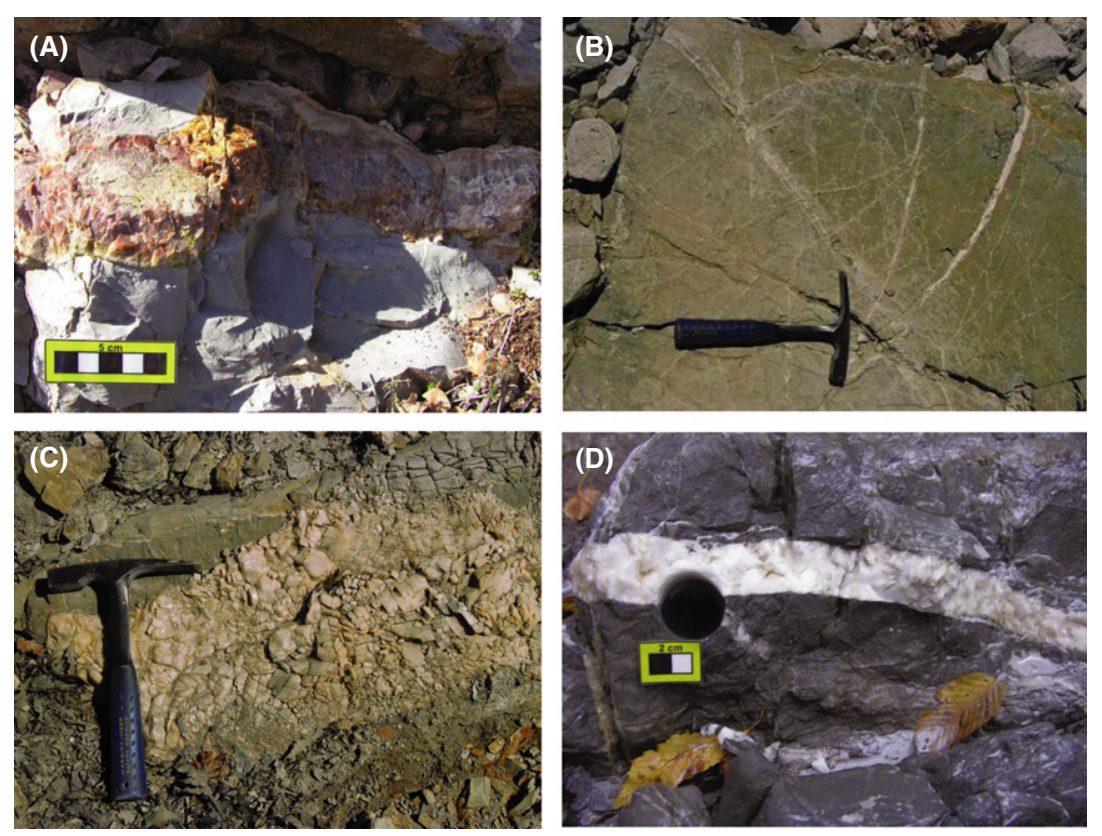

Fig. 5. Field photographs illustrating the main sampled formations and hosted calcite veins. (A) Grey limestones with continuous chert levels (Calcari con Selce Fm) from Monte Cetona. (B) Variously oriented calcite veins from the Calcare Massiccio Fm at Poggio Zoccolino. (C) Close view of a large vein made of calcite spatic rhombohedra hosted by the Calcare Massiccio Fm from Poggio Zoccolino. (D) Calcite vein from the south-eastern flank of the Monte Amiata (Solforate Mine) hosted by siliciclastic cap rocks of the Ligurian Units.

Fluid inclusion microthermometry was carried out with a Linkam MDS 600 stage, calibrated with synthetic FIs and mounted on a Nikon LV100 Eclipse associated with a 100-W Mercury vapour lamp, which allowed UV-light microscopy. The Linksys 32 software enabled all the operations for FI microthermometry. Salinities were calculated from final melting of ice $\left(\mathrm{Tm}_{\mathrm{i}}\right)$ in the binary $\mathrm{H}_{2} \mathrm{O}-\mathrm{NaCl}$ system (Bodnar 1993). Raman spectrometry was accomplished on FIs in thick sections at room temperatures. Liquid and gas phases in the largest FIs close to the sample surface were analysed by a LABRAM confocal Raman spectrometer using for radiation a $532.2 \mathrm{~nm}$ wavelength (green laser).

Carbonate powders destined to geochemical analysis were extracted from polished rock slabs by means of a dental drill. About 60 oxygen $(\mathrm{O})$ and carbon $(\mathrm{C})$ isotope analyses were performed. Carbonate powders were reacted with $100 \%$ phosphoric acid at $70^{\circ} \mathrm{C}$ using a Gasbench II connected to a Thermo Finnigan Five Plus mass spectrometer. All values are reported in per mil relative to $\mathrm{V}-\mathrm{PDB}$ by assigning a $\delta^{13} \mathrm{C}$ value of +1.95 and a $\delta^{18} \mathrm{O}$ value of -2.20 to NBS19. Reproducibility was checked by replicate analysis of laboratory standards and is better than \pm 0.05 for $\delta^{18} \mathrm{O}$ and \pm 0.06 for $\delta^{13} \mathrm{C}$. Oxygen isotope values were corrected using the phosphoric acid fractionation factors given by Kim et al. (2007) and Rosenbaum \& Sheppard (1986).

More than 30 strontium $(\mathrm{Sr})$ isotope analyses were carried out on $1 \mathrm{mg}$ of powder in a $2.5 \mathrm{M} \mathrm{HCl}$. The separation between the two components was performed by the standard procedure of ionic exchange. Samples were loaded on to single Re filaments and run on a VG Sector $54 \mathrm{e}$ thermal ionization mass spectrometer. The ${ }^{87} \mathrm{Sr} /{ }^{86} \mathrm{Sr}$ values were then normalized to a ratio value of ${ }^{87} \mathrm{Sr} /{ }^{86} \mathrm{Sr}=0.1194$. The precision was better than \pm 0.04 .

Tens of samples were analysed for minor and trace elements by inductively coupled plasma mass spectrometry (ICP-MS) at ACME Analytical Laboratories Ltd. (Vancouver, Canada). Sample splits of 0.25 and $0.5 \mathrm{~g}$ could be analysed. Prepared samples were digested with a modified Aqua Regia solution of equal parts concentrated $\mathrm{HCl}$, $\mathrm{HNO}_{3}$ and $\mathrm{DI} \mathrm{H}_{2} \mathrm{O}$ for $\mathrm{l} \mathrm{h}$ in a heating block of hot water bath. Samples were made up to volume with dilute $\mathrm{HCl}$.

\section{VEIN PETROGRAPHY}

For detailed sedimentological and microfacies analysis of the Tuscan Nappe succession, refer to Kalin et al. (1979) and to Bambini et al. (2010). Beside fracturing and vein mineralization (i.e. the object of this study), the different formations underwent several diagenetic episodes including eogenetic mechanical compaction (grain rearrangement and disruption) and marine calcite cementation (granular crystals and more locally fibrous circumgranular rims), followed by mesogenetic chemical compaction (stylolites, solution seams) and recrystallization (crystal coarsening, dolomite textural changes, silica remobilization in chertrich sediments). 

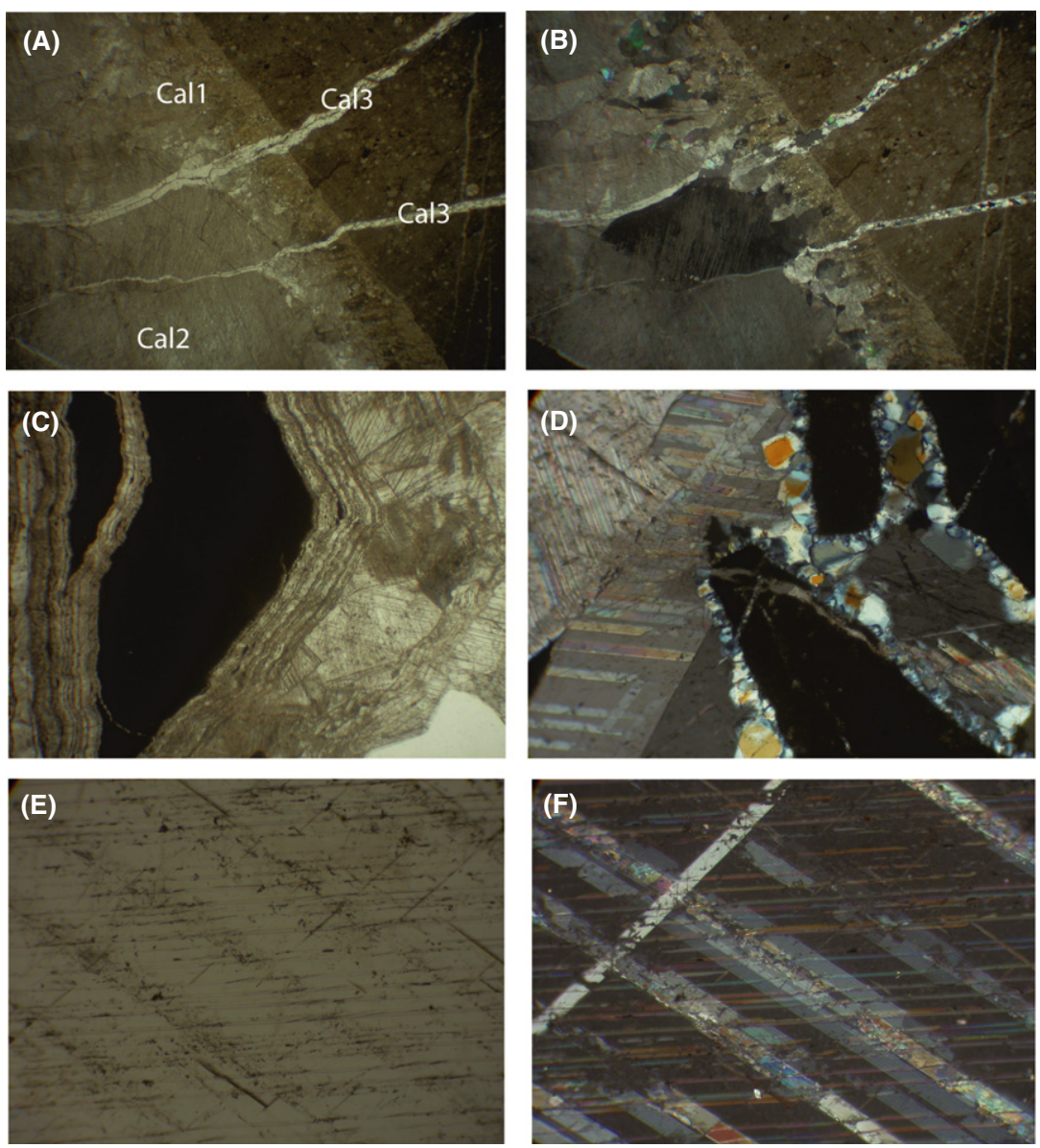

Fig. 6. Petrographic photomicrographs illustrating different vein calcites from Poggio Zoccolino. (A) Diagenetic Cal1 vein, reopened by syn-tectonic Cal2 vein, both postdated by a thin vein of Cal3. Long side is $2 \mathrm{~mm}$. Plane-polarized light. (B) Same under cross-polarized light. (C) Blocky Cal4 filling a re-opened fracture displaying an older crack-seal vein. Long side is $2 \mathrm{~mm}$. Plane-polarized light. (D) Blocky Cal4 fills a vein after hydraulic fracturing and quartz precipitation. Long side is $1.5 \mathrm{~mm}$. Crossed-polarized light. (E) Particular of spatic rhombohedra of Calcite 5 displaying cleavage planes controlling the distribution of some pseudosecondary inclusions (dark points). Long side is $1 \mathrm{~mm}$. Plane-polarized light. (F) Same under cross-polarized light. Cleavage planes are better seen.

Different vein calcites were petrographically distinguished based on crystal habitus, growth features, response under $\mathrm{CL}$, relationship with the hosts, as well as cross-cutting relationships and were inserted in a paragenetic scenario. The vein mineralization from Poggio Zoccolino area (Fig. 1) consists of five different late vein calcites named from Call to Cal5 (see Fig. 6). Early veins, due to eogenetic to shallow mesogenetic compaction of not fully consolidated sediments, are not detailed here, as the main focus is on late fluid circulation processes.

Call is dominantly represented by fibrous crystals growing perpendicular to the host-vein contact and commonly according to an antitaxial arrangement, suggesting crystal growth contemporaneous with fracture opening. Crack-seal features were also locally observed. Call displays a uniform dull red CL and sharp contact with the host rock. These veins possibly formed during burial diagenesis, as deduced from cross-cutting relationships with bedding parallel stylo- lites, formed by normal lithostatic overburden. FIs were observed mainly along growth directions, but the fine and cloudy crystal nature did not allow their characterization.

Cal2 is a blocky to elongated blocky calcite with common crystal size increase towards the vein centre. Locally, it represents a phase of re-opening and refilling of previous fractures. In the latter case, the transition from Call to Cal2 is commonly abrupt. The crystals have straight twins and uniform dull red CL. They mainly host biphase liquid-rich FIs, especially concentrated along growth zones or in crystal cores, with negative crystal shapes or controlled by crystallographic directions, which were further investigated (Fig. 7A and B).

Cal3 comprises granular to fine blocky calcite crystals and postdates both Call and Cal2. It displays a uniform brighter red CL. The clearness of the crystals suggests a relative lack of FIs.

Both Cal2 and Cal3 are interpreted as formed during collisional to postcollisional tectonic events, as deduced by 

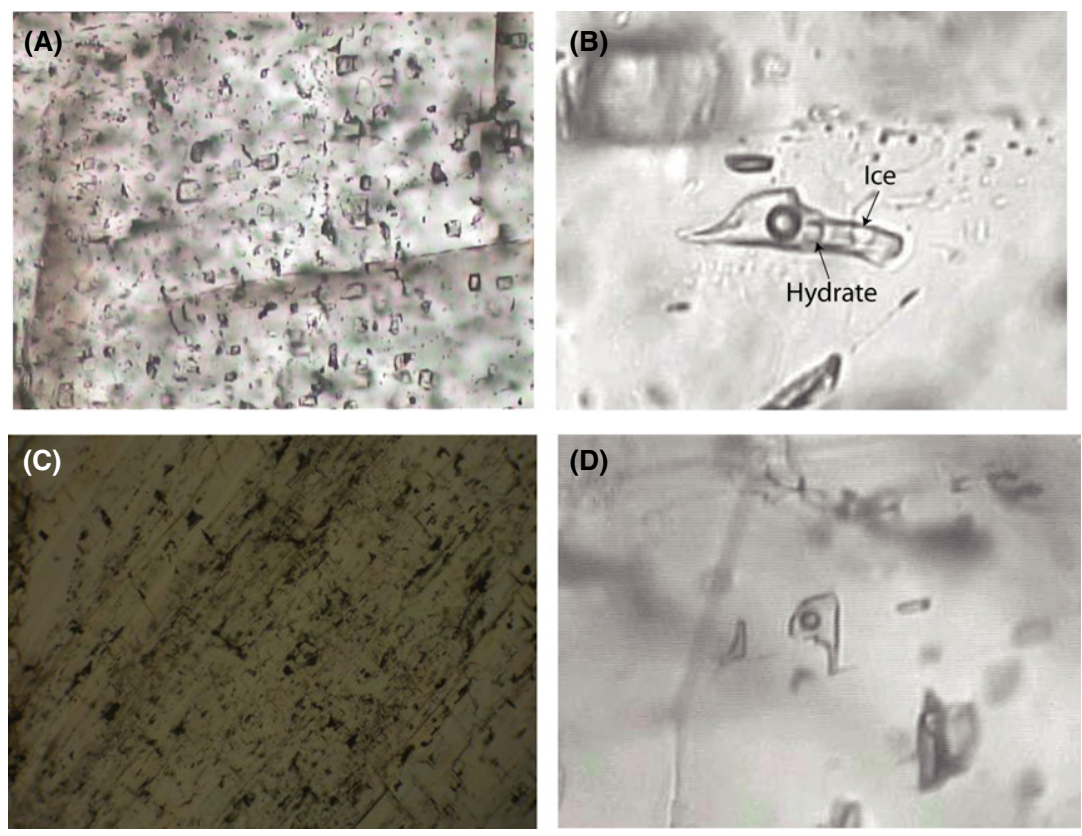

Fig. 7. Petrographic photomicrographs illustrating fluid inclusions (FIs) from the vein calcites of Poggio Zoccolino area. Plane-polarized light. (A) Primary Fls in Cal2 concentrated in crystal cores showing negative crystal to crystallographic controlled shapes. Long side is $600 \mu \mathrm{m}$. (B) Large biphase liquid-rich $\mathrm{Fl}$ in $\mathrm{Cal} 2$ during freezing experiments. At $-24^{\circ} \mathrm{C}$, both ice and salt hydrate crystals are present. Long side is $70 \mu \mathrm{m}$. (C) Primary Fls uniformly distributed throughout a Cal5 crystal. Long side is $700 \mu \mathrm{m}$; (D) Particular of Fls in a Cal5 crystal showing crystallographic controlled shapes. Long side is $60 \mu \mathrm{m}$.

cross-cutting relationship with the previous diagenetic veins and by their array and fabric, often characterized by en-echelon arrangements (Fig. 5B).

Cal4 is given by coarse blocky crystals with straight to patchy twins, uniform dull to bright orange CL and sharp contacts with the host rock. Cal4 veins may re-open previous fractures. They contain abundant monophase all-liquid and biphase liquid-rich FIs, uniformly distributed through the crystals and with negative crystal shapes or controlled by crystallographic directions (cleavage). Microthermometry was accomplished on the biphase aqueous FIs.

Cal5 is given by very large (up to few $\mathrm{cm}$ ) rhombohedra of spatic calcite with straight twins and uniform dull orange CL. No crystal size variation was observed towards the fracture centre. Crystallographic planes (cleavage) and growth zones control the distribution of FIs, mostly biphase liquid-rich and with rectangular to negative crystal shapes (Fig. 7C and D), which were used for microthermometry and Raman investigations.

Both Cal4 and Cal5 veins occur mainly in the Calcare Massiccio Fm and to a less extent in the overlaying formations. They postdate the previous syn-tectonic Cal2 and Cal3 veins.

For comparison, late calcite veins were studied from the Solforate area (Fig. 1). The fracture-filling calcite, named Cal6, consists of coarse blocky crystals, displays sharp contacts with the hosts and is associated with sparse $\mathrm{HgS}$ mineralization and locally dawsonite (Fabbrini 2010). The crystals are characterized by very abundant and relatively large primary FIs, concentrated in the crystal cores or along growth zones. These FIs are dominantly monophase liquid, with subordinate biphase liquid-rich ones, which were further investigated.

According to field and petrographic observations, these calcite veins were assembled in three groups: GROUP-1 including Cal2 and Cal3 filled fractures, GROUP-2 including Cal4 and Cal5 veins and GROUP-3 given by the Cal6 veins. The burial diagenetic Call veins formed by stress transmitted from normal lithostatic load were not discussed.

\section{ANALYTICAL RESULTS}

\section{Fluid inclusions study}

Petrographic analysis revealed that Cal2 (GROUP-1 veins) as well as Cal4 and Cal5 (GROUP-2 veins) from Poggio Zoccolino (Fig. 1) were dominated by aqueous biphase liquid-rich FIs, suitable for microthermometry measurements. Three Cal6 samples of GROUP-3 veins from Solforate (Fig. 1) were also investigated. Details concerning the FI petrographic features and the results of microthermometry are summarized in Table 1.

Biphase FIs in Cal2 were investigated from three vein samples. They are given by an aqueous solution and a vapour bubble in the absence of any other gas species detectable by Raman. Homogenization occurred in the liquid phase at temperatures between 100 and $250^{\circ} \mathrm{C}$, with 


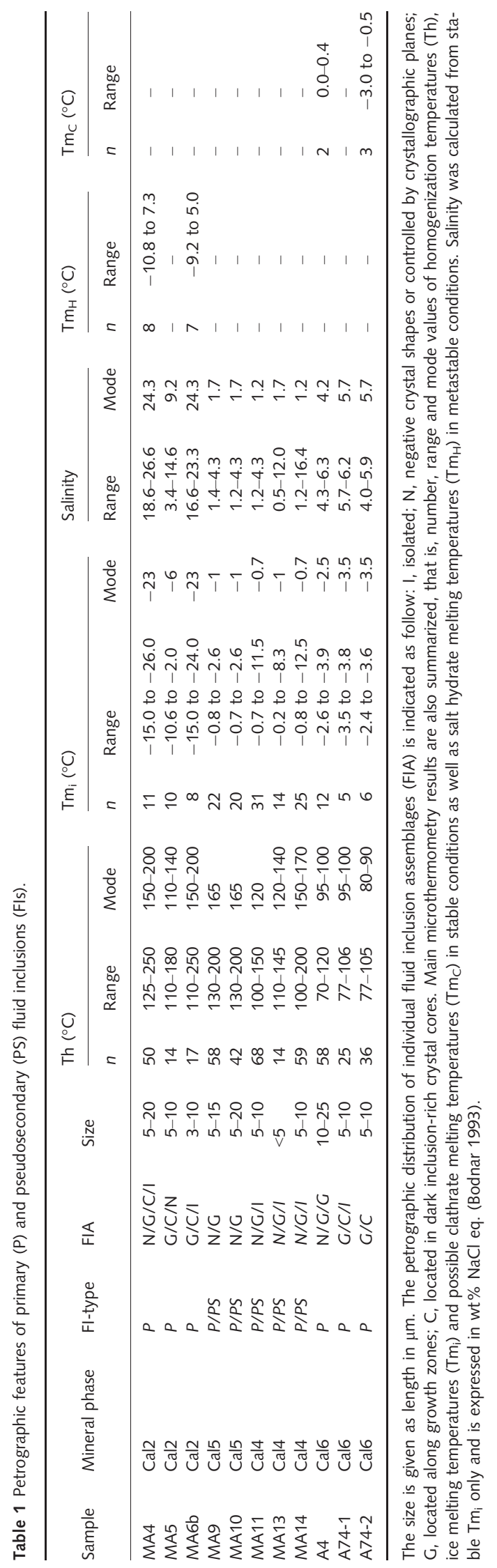

most of the values falling in the range 110 and $210^{\circ} \mathrm{C}$ (Fig. 8A). This flat frequency distribution of Th data suggests that most FIs underwent re-equilibration and/or leakage. The leakage phenomena were also petrographically confirmed by the presence of some clearly leaked FIs (Th not measured). During freezing runs, eutectic point was observed at temperatures lower than $-40^{\circ} \mathrm{C}$, indicating the presence of a complex mixture of salts (including $\mathrm{CaCl}_{2}$ ), rather than only $\mathrm{NaCl}$. For two samples (MA4 and MA6b), ice was the next phase to melt. $\mathrm{Tm}_{\mathrm{i}}$ occurred at temperatures between -26 and $-15^{\circ} \mathrm{C}$ with a mode at $-23 /-24^{\circ} \mathrm{C}$ (Table 1 and Fig. $8 \mathrm{~B}$ ). In many FIs, colourless and high relief crystals of salt hydrate (possibly hydrohalite) were still present after ice melting. The salt hydrate crystals $\left(\mathrm{Tm}_{\mathrm{H}}\right)$ melted metastably at temperatures with no thermodynamic meaning (Table 1). Salinities were therefore calculated in the binary $\mathrm{H}_{2} \mathrm{O}-\mathrm{NaCl}$ system using the stable $\mathrm{Tm}_{\mathrm{i}}$ and gave values in the range of 16.6 to 26.6 (mode is 24 ) wt\% $\mathrm{NaCl}$ eq., which represent an underestimation of the real fluid salinities. For one sample (MA5), final melting of ice $\left(\mathrm{Tm}_{\mathrm{i}}\right)$ occurred mostly between -5 and $-7^{\circ} \mathrm{C}$ with mode at $-6^{\circ} \mathrm{C}$, corresponding to a mode salinity of $9.2 \mathrm{wt} \% \mathrm{NaCl}$ eq. (Table 1 and Fig. $8 \mathrm{~B}$ ).

Biphase FIs from the blocky Cal4 were investigated from three vein samples. The FI size and the strong host mineral fluorescence effects hindered any Raman analysis. Homogenization in the liquid phase occurred at temperatures in the range of 100 to $200^{\circ} \mathrm{C}$ (Fig. 8C), with a broad mode between 120 and $160^{\circ} \mathrm{C}$. Ice-like phases nucleated during the first cooling run at temperatures between -35 and $-45^{\circ} \mathrm{C}$. More then half of the FIs displayed metastable behaviour during melting. Stable final melting of ice felt in a large range of temperatures between -0.2 and $-12.5^{\circ} \mathrm{C}$. Nevertheless, by observing the $\mathrm{Tm}_{\mathrm{i}}$ frequency distribution in Fig. 8D, a dominant and fairly consistent mode appears at -0.7 to $-1.0^{\circ} \mathrm{C}$, corresponding to a mode salinity of $1.2-1.7 \mathrm{wt} \% \mathrm{NaCl}$ eq. The lower $\mathrm{Tm}_{\mathrm{i}}$, which is much less represented, corresponds to variable salinities (6-16 wt\% $\mathrm{NaCl}$ eq.) with no defined mode (Fig. 8D).

Biphase FIs from Cal5 spatic rhombohedra were investigated from two vein samples. The presence of gas under pressure higher than 1 bar within the vacuoles was suggested by moderate bubble expansion after crushing. Because the bubble expanded but did not occupied the total volume of the inclusions on crushing, the approximate $\mathrm{CO}_{2}$ content of these inclusions (between 0.15 and $0.35 \mathrm{wt} \%$ ) was estimated on the basis of their Th and salinity modes using the graphical method of Sasada (1985). Raman spectroscopy at room temperature confirmed the presence of $\mathrm{CO}_{2}$ in the largest FIs, by the appearance of two of the characteristic peaks at 1224 and $1387 \mathrm{~cm}^{-1}$ (Frezzotti et al. 2012). Homogenization temperatures are various, but mainly between 130 and $200^{\circ} \mathrm{C}$. They plot according to a normal distribution of data with a large 

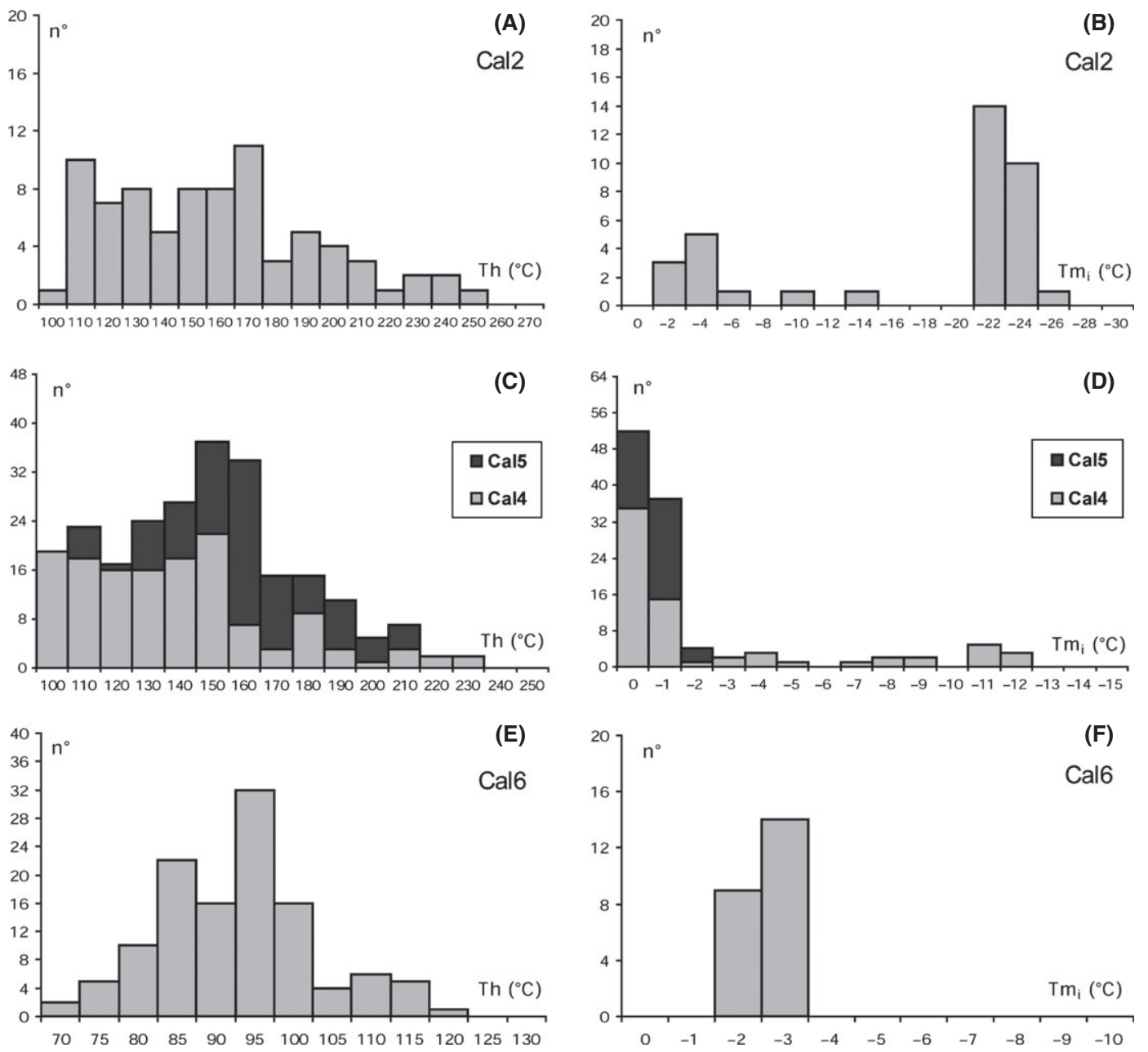

Fig. 8. Results of microthermometry. Frequency distribution for homogenization temperatures (Th) and melting of ice ( $\left.T m_{i}\right)$ for the different calcite vein groups. (A) Th, GROUP-1. (B) $T m_{i}$, GROUP-1. (C) Th, GROUP-2. (D) $T m_{i}$, GROUP-2. (E) Th, GROUP-3. (F) $T m_{i}$, GROUP-3.

mode at $165^{\circ} \mathrm{C}$ (Fig. 8E). Gas bubble nucleation occurred upon cooling towards room temperatures after homogenization. During reheating after freezing, a first liquid was optically seen at temperatures as low as $-12^{\circ} \mathrm{C}$, representing the upper constrain of the real eutectic points and suggesting $\mathrm{NaCl}$ as the dominant dissolved salt. Ice was the last phase to melt at temperatures between -0.7 and $-2.6^{\circ} \mathrm{C}$, with a well-defined mode at $-1^{\circ} \mathrm{C}$ (Fig. $8 \mathrm{~F}$ ), corresponding to a mode salinity of $1.7 \mathrm{wt} \% \mathrm{NaCl}$ eq.

Similarities between petrographic features and Th among Cal4 and Cal5 FIs suggest that they were trapped from a fluid belonging to the same system. Some discrepancies arise from the $\mathrm{Tm}_{\mathrm{i}}$ distribution for the two calcites types, with the Cal4 recording also a tail of lower $\mathrm{Tm}_{\mathrm{i}}$ (Fig. 8D) and correspondent higher salinities, and will be discussed later.

Cal6 crystals from Solforate are dominated by monophase liquid FIs. Several cycles of moderate cooling were unsuccessfully carried out to induce gas bubble nucleation. Microthermometry was performed on the less common biphase liquid-rich FIs. Homogenization temperatures in the liquid phase occurred in the interval $70-120^{\circ} \mathrm{C}$, displaying a normal distribution of data with a well-defined mode at $90-95^{\circ} \mathrm{C}$ (Fig. $8 \mathrm{E}$ ). The gas bubble did not nucleate after homogenization and subsequent cooling to room (or lower) temperatures. Occasionally, the bubble reappeared in leaked FIs, upon reheating after freezing. This behaviour suggests that also the common monophase liquid FIs are the result of the non-nucleation of a gas bubble due to metastability, rather than of low trapping temperatures. This is supported by the evidence that monophase and biphase FIs coexist in the same assemblage and display similar size and shapes. The few biphase FIs were investigated by freezing experiments. More than $50 \%$ of them displayed metastable final melting, with ice and associated hydrate phases melting abruptly. Less commonly, FIs displayed stable ice melting in the range -2.4 to $-3.9^{\circ} \mathrm{C}$, with a clear mode at $-3^{\circ} \mathrm{C}$, corresponding to a mode salinity of $5 \mathrm{wt} \% \mathrm{NaCl}$ eq. In five FIs, after the ice melting, an other phase was still present and melted stably 
at temperatures of -3 to $0.4^{\circ} \mathrm{C}$. This was a colourless noncrystalline phase, forming rims around the gas bubbles and very difficult to see. Its presence was detected by the moving behaviour of the bubble during cycling and could be a clathrate phase.

\section{Isotope and element geochemistry}

The results of $\mathrm{O}-\mathrm{C}$ and $\mathrm{Sr}$ isotope analysis from samples of the different Tuscan Nappe formations cropping out in the Monte Cetona area (Fig. 1) are reported in Fig. 9 along profiles, beside a schematic stratigraphic column, covering a succession about 1000 metre thick. With some fluctuations, which mainly depend on seawater evolution through time and sedimentological heterogeneities among formations, the whole succession displays quite a consistent isotopic composition. In particular, the carbonates from the Burano Fm (pink in Fig. 9) have $\delta^{18} \mathrm{O}, \delta^{13} \mathrm{C}$ and ${ }^{87} \mathrm{Sr} /{ }^{86} \mathrm{Sr}$ in the range of -2.2 to $-3.2,2.8$ to 3.4 and 0.70788 to 0.70798 , respectively. The Calcare a Rhaetavicuola contorta Fm and the Calcare Massiccio Fm (blue in Fig. 9) display $\delta^{18} \mathrm{O}, \delta^{13} \mathrm{C}$ and ${ }^{87} \mathrm{Sr} /{ }^{86} \mathrm{Sr}$ in the range of -0.9 to $-2.0,1.6$ to 2.6 and 0.70773 to 0.70791 , respectively. The Calcare Rosso Ammonitico Fm (green in Fig. 9) exhibits $\delta^{18} \mathrm{O}, \delta^{13} \mathrm{C}$ and ${ }^{87} \mathrm{Sr} /{ }^{86} \mathrm{Sr}$ in the range of -0.7 to $-1.4,2.5$ to 3.0 and 0.70764 to 0.70780 , respectively. Finally, the Calcare Selcifero Fm and the Marne a Posidonia Fm (violet in Fig. 9) have $\delta^{18} \mathrm{O}, \delta^{13} \mathrm{C}$ and ${ }^{87} \mathrm{Sr} /{ }^{86} \mathrm{Sr}$ in the range of -0.4 to $-2.2,0.0$ to 0.5 and 0.70770 to 0.70780 , respectively.

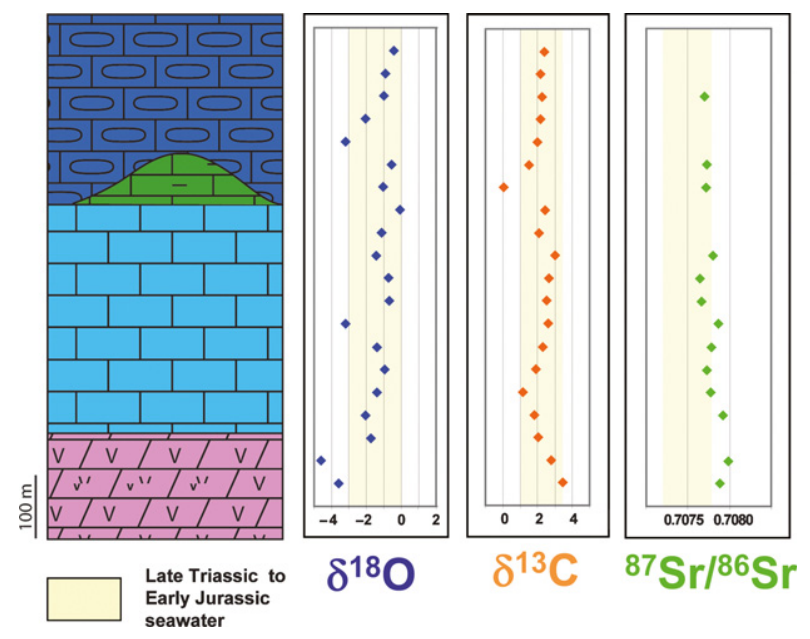

Fig. 9. Isotope geochemistry of the Tuscan Nappe from the Monte Cetona area. The diagrams refer to $\mathrm{O}, \mathrm{C}$ and $\mathrm{Sr}$ isotopes, respectively. $\delta^{18} \mathrm{O}$ and $\delta^{13} \mathrm{C}$ are expressed in per mil PDB. On the left a schematic stratigraphic column including the Burano Fm (in pink), the Calcare a Rhaetavicuola contorta Fm and Calcare Massiccio Fm (in blue), the Calcare Rosso Ammonitico Fm (in green), as well as the Calcare Selcifero Fm and the Marne a Posidonia Fm (in violet). The light yellow areas refer to isotopic values for marine carbonates precipitated in equilibrium with Late Triassic to Early Jurassic seawater (from Veizer et al. 1999).
The isotope composition of calcites precipitated in equilibrium with Late Triassic to Early Jurassic seawater is reported as well (Fig. 9), by considering the $\pm 1 \sigma$ values, including $68 \%$ of the samples from the seawater Phanerozoic curves of Veizer et al. (1999), i.e. $\delta^{18} \mathrm{O}, \delta^{13} \mathrm{C}$ and ${ }^{87} \mathrm{Sr} /{ }^{86} \mathrm{Sr}$ in the range of -3 to 0,1 to 3.5 and 0.7072 to 0.7077 , respectively. It comes out that most values from the Monte Cetona samples overlap those of carbonates precipitated from coeval seawater. The slightly more negative $\delta^{18} \mathrm{O}$ of the Burano $\mathrm{Fm}$ is explained by the dominance of dolomitic lithologies, commonly more depleted in ${ }^{18} \mathrm{O}$ compared with coeval calcites (fractionation effect; Land 1980). On the other hand, the tendency of the analysed samples to overlap the uppermost range of ${ }^{87} \mathrm{Sr} /{ }^{86} \mathrm{Sr}$ coeval seawater values (and locally to be slightly more radiogenic) is possibly due to recrystallization effects during burial diagenesis, driven by water-rock interaction.

Isotope data from samples of the different Tuscan Nappe formations cropping out in the Poggio Zoccolino area (Fig. 1) are reported as cross-plots in Fig. 10. Here, the sampling was conducted by separating the different vein calcites previously distinguished by petrography and fluid inclusion analysis (i.e. GROUP-1 and GROUP-2) as well as the correspondent host rocks. In the cross-plots, together with the coeval seawater composition (Veizer et al. 1999), are reported also the few data available in literature for the Tuscan Nappe from northern Apennines outcrops (Cortecci \& Lupi 1994). Two distinct clouds are obtained from GROUP-1 to GROUP-2 calcite veins and relative host samples. The good overlap between the two groups of veins and their host rocks (Fig. 10) suggests equilibrium conditions among them.

In particular, GROUP-1 calcites (given by Cal2) display $\delta^{18} \mathrm{O}, \delta^{13} \mathrm{C}$ and ${ }^{87} \mathrm{Sr} /{ }^{86} \mathrm{Sr}$ in the range of -2.7 to -5.3 , 1.1 to -2.3 and 0.7088 to 0.7076 , respectively, whereas their hosts have $\delta^{18} \mathrm{O}, \delta^{13} \mathrm{C}$ and ${ }^{87} \mathrm{Sr} /{ }^{86} \mathrm{Sr}$ in the respective range of -1.4 to $-4.9,1.2$ to 2.7 and 0.7075 to 0.7081 . These GROUP-1 samples (both calcites and hosts) show a $\delta^{13} \mathrm{C}$ typically inherited from the marine carbon, but $\delta^{18} \mathrm{O}$ shifted towards lower values and slightly more radiogenic ${ }^{87} \mathrm{Sr} /{ }^{86} \mathrm{Sr}$ relative to oxygen and strontium marine signatures (Veizer et al. 1999). The Poggio Zoccolino samples result to be isotopically similar to diagenetically altered carbonates of the Tuscan Nappe from areas, which underwent thermal events, during the collisional stages of northern Apennines emplacement (Cortecci \& Lupi 1994).

GROUP-2 calcites (given by both Cal4 and Cal5) only present in the Poggio Zoccolino area display $\delta^{18} \mathrm{O}, \delta^{13} \mathrm{C}$ and ${ }^{87} \mathrm{Sr} /{ }^{86} \mathrm{Sr}$ in the range of -7.5 to $-9.0,0.6$ to -2.6 and 0.7095 to 0.7117 , respectively, whereas their host rocks have $\delta^{18} \mathrm{O}, \delta^{13} \mathrm{C}$ and ${ }^{87} \mathrm{Sr} /{ }^{86} \mathrm{Sr}$ in the respective range of -8.2 to $-12.8,1.1$ to -2.5 and 0.7088 to 0.7119 . These values are fairly different compared with the previously described carbonates (Figs 9 and 10). The hosts 

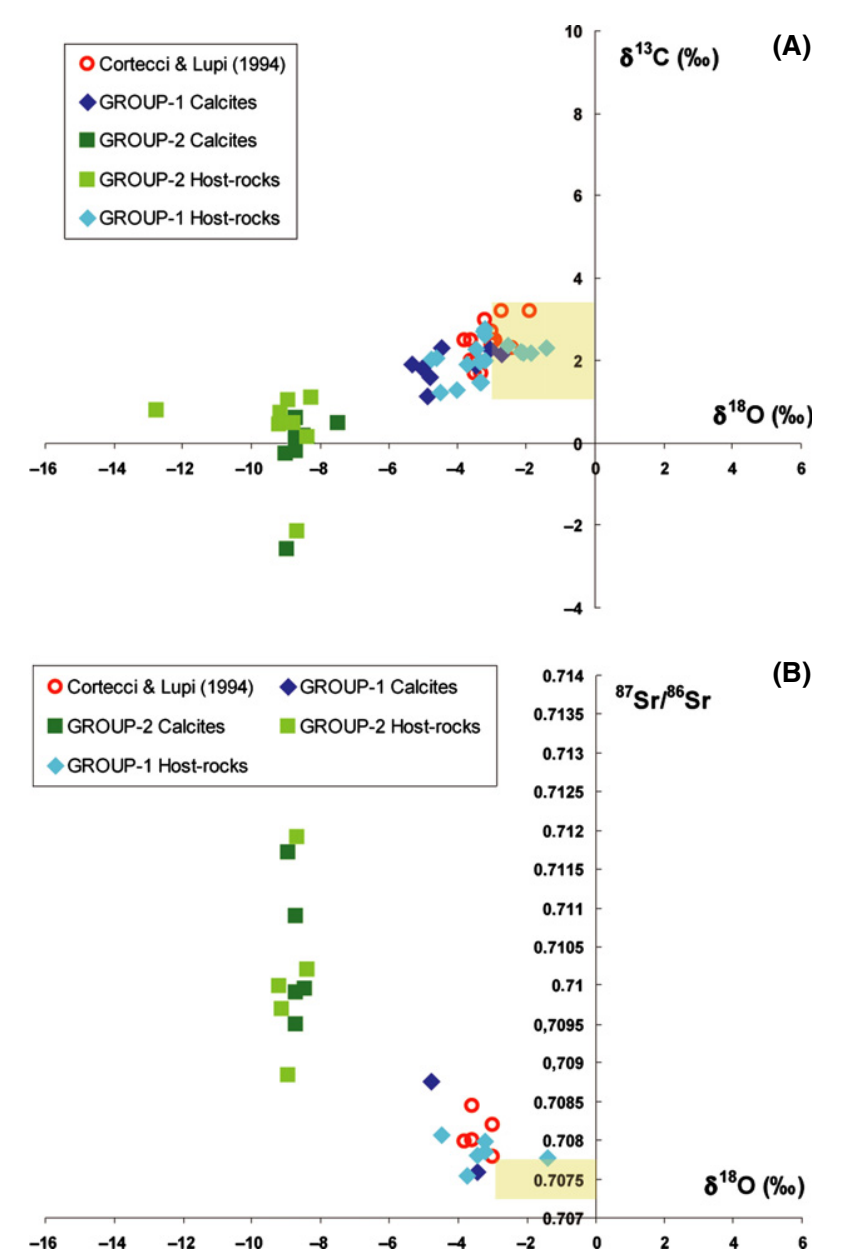

Fig. 10. Cross-plots from isotope analysis on the studied phases. Light yellow squares indicate values of marine Late Triassic to Early Jurassic seawater (Veizer et al. 1999). Red circles refer to samples of the Tuscan Nappe from northern Apennines areas not disturbed by hydrothermal fluid circulation (Cortecci \& Lupi 1994). (A) $\delta^{18} \mathrm{O}-\delta^{13} \mathrm{C}$. (B) $\delta^{18} \mathrm{O}-{ }^{87} \mathrm{Sr} /{ }^{86} \mathrm{Sr}$.

of GROUP-2 calcite veins reflect the isotope composition of the calcites. Both vein and host samples display strongly depleted $\delta^{18} \mathrm{O}$, lighter $\delta^{13} \mathrm{C}$, as well as more radiogenic ${ }^{87} \mathrm{Sr} /{ }^{86} \mathrm{Sr}$, compared to the Tuscan Nappe carbonates from Monte Cetona (Fig. 9), Poggio Zoccolino (GROUP-1, Fig. 10) and northern Apennines (Cortecci \& Lupi 1994; Fig. 10), suggesting that they were related to a different fluid circulation history.

The analysed vein calcites of GROUP-3 from the Solforate area (Fig. 1) show $\delta^{18} \mathrm{O}$ between -16.2 to -20.5 and $\delta^{13} \mathrm{C}$ between 1.2 to 3.8 (results not reported in the figures). The host rocks, represented by shaly marls and sandstones, were not taken into account.

Major, minor and trace element analysis were achieved on both calcites and host rocks from the different localities. The GROUP-2 calcites and correspondent hosts display a variable enrichment in $\mathrm{Fe}, \mathrm{Mn}$ and $\mathrm{Sr}$ and to a less extent in $\mathrm{Ba}$ and $\mathrm{Ni}$ compared with GROUP-1 calcites and relative hosts. This supports the idea that the composition of the host carbonates was reset by the composition of the different calcite parent fluids they interacted with.

\section{FLUID SYSTEM CHARACTERIZATION AND EVOLUTION}

A geochemical study of carbonate fracture fills occurring through the Tuscan Nappe of the Monte Amiata area was undertaken together with a detailed FI study to constrain the nature and origin of the fluids precipitating the calcites and especially those related to the $\mathrm{CO}_{2}$ migration events. Particular emphasis was placed on two main groups of calcite veins (GROUP-1 and GROUP-2) sampled from outcrops at Poggio Zoccolino (Fig. 1) and to a minor extent on a third group of veins (GROUP-3) outcropping at Solforate (Fig. 1). Based on FI and geochemistry data (Figs 8, 9, 10 and Table 1), these calcite veins are considered to have formed prior to or concomitant with $\mathrm{CO}_{2}$ migration events through the studied succession. The collected data set allowed distinguishing three broad stages of fluid circulation.

\section{Stage 1}

A first stage of fluid circulation occurred during syn-tectonic deep burial and gave origin to different GROUP-1 veins, which equilibrated with the carbonate hosts (see overlap of isotopic data in Fig. 10). These veins precipitated from either moderate saline solutions $(9.2 \mathrm{wt} \% \mathrm{NaCl}$ eq.; sample MA5 in Table 1) or highly saline ones (>23 wt $\% \mathrm{NaCl}$ eq.; samples MA4 and MA6b in Table 1). The dissolved salts possibly derived from fluid interaction with the underlying evaporitic Burano Fm and the discrepancy in salinity values among the analysed samples could reflect variable degrees of such interaction at different substages of the syn-tectonic burial history. Nevertheless, the sharing of petrographic and geochemical features (Fig. 10) and the similar high temperature FI behaviour (Table 1) allow to consider GROUP-1 veins as precipitated from a common burial fluid system, here named FLUID-1, although at different moments of the syn-tectonic evolution of the study area. The re-equilibration recorded by most FIs (Fig. 8A and Table 1) may reflect overheating during collision or pressure release during uplift. During the orogenetic phase, the study area experienced thermal episodes, recorded also in the clay-rich succession of the Ligurian Units by Battaglia et al. (2007). These authors used clay mineral reactions as indicators of low-to-very low-grade metamorphism and concluded that during orogenesis, the succession was affected by regional metamorphism, corresponding to the highest grade of the diagenetic zone, close to the anchizone transition boundary (approximately $200 \pm$ $50^{\circ} \mathrm{C}$ ). Illite crystallinity analysis on pelitic and marly rocks 
of the Liguride Units from the same area confirms the highest grade of diagenesis to anchimetamorphism experienced by the succession (Franceschelli et al. 1994). Similar data derive from illite crystallinity analyses on the carbonates (Marne a Posidonia Fm) of the Tuscan Nappe exposed in the western side of the Monte Amiata (Brogi 2006). The re-equilibration recorded by the primary FIs of GROUP-1 syn-tectonic veins accounts for homogenization temperatures in the same range (Fig. $8 \mathrm{~A}$ and Table 1 ). It is proposed here that the re-equilibration was linked to the further overburden and consequent overheating of the Tuscan Nappe during the Appennine orogenesis and associated regional metamorphism.

\section{Stage 2}

GROUP-2 veins (including both Cal4 and Cal5) from Poggio Zoccolino record a later stage of fluid circulation, which reset the geochemistry of the carbonate hosts (see overlap of isotopic data in Fig. 10). The calcites precipitated from a moderately hot (mode $\mathrm{Th}$ is $165^{\circ} \mathrm{C}$ ), poorly saline $(1.2-4.3$ wt\% $\mathrm{NaCl}$ eq.), $\mathrm{CO}_{2}$-bearing (Raman spectra on gas bubbles) aqueous system named FLUID-2 (Fig. 8 and Table 1), carrying more radiogenic $\mathrm{Sr}$ and light ${ }^{12} \mathrm{C}$ (Fig. 10) compared with the burial syn-tectonic FLUID-1.

The temperatures inferred for FLUID-2 are lower than those related to the regional anchimetamorphism (Franceschelli et al. 1994; Battaglia et al. 2007). Evidences of this cooler event are found again in the Ligurian Units of the Monte Amiata area (Battaglia et al. 2007). Indeed, after the regional anchimetamorphism (approximately $200 \pm 50^{\circ} \mathrm{C}$ ), the clay fraction was involved in a widespread alteration, consisting of illite destabilization with subsequent formation of kaolinite and I-S phases, both typical of low-temperature assemblages consistent with retrograde reactions. Battaglia et al. (2007) explain such changes as due to hydrothermal fluid circulation, activated by a geothermal anomaly, under typical diagenetic conditions $\left(175 \pm 25^{\circ} \mathrm{C}\right)$. Also the initial temperature of the shallow carbonate-evaporite reservoir of the Bagnore geothermal field was estimated to be of about $175^{\circ} \mathrm{C}$ (Atkinson et al. 1978). These temperature values are comparable with homogenization temperatures of FLUID-2 (in the assumption of a shallow hydrothermal system, the Th pressure correction is irrelevant). These data altogether allow to interpret FLUID-2 as derived from a meteoric water, feeding a past geothermal system and charged in $\mathrm{CO}_{2}$ of deep origin, like it occurs in the present-day reservoirs (Fig. 3B). The Tuscan Nappe rocks from Poggio Zoccolino were therefore affected by the circulation of leaked $\mathrm{CO}_{2}$-rich fluids from a past geothermal system.

The radiogenic Sr signature of FLUID-2 (Fig. 10) most likely reflects this meteoric origin (surface fluids after continental weathering have ${ }^{87} \mathrm{Sr} /{ }^{86} \mathrm{Sr}$ values consistently higher compared with modern seawater; Faure 1986); further ${ }^{87} \mathrm{Sr}$ enrichment was achieved during interaction with the reservoir rocks of the geothermal system. In this respect, highly radiogenic Sr sources could have been represented by dissolution of detrital feldspars and clays from the shaly to marly horizons of the nodular Calcare Rosso Ammonitico Fm.

FLUID-2 salinity variation (Fig. 8D) observed only in Cal4 blocky crystals and not in Cal5 rhombohedric crystals may be explained by: 1. boiling phenomena in the geothermal fluid; 2. Recrystallization of previous calcites and partial FI refill. Boiling of fluids is very common in shallow geothermal systems and may account for the simultaneous trapping of FIs with different salinity. In particular, opensystem isothermal boiling, where the heat is supplied by the country rocks could explain local, isolated high-salinity enrichment (e.g. Simmons \& Browne 1997). However, the absence of vapour-rich inclusions and of variable liquid -vapour phase proportions in FIs from the same assemblage does not support this hypothesis. According to a more likely scenario, the blocky Cal4 precipitated from FLUID-2 after re-opening of previous veins formed from the saline FLUID-1 system. The Cal4 precipitation was accompanied by local replacement (and FI refill) of the older calcites. The FI refill process was not complete: indeed, some of the highly saline FLUID-1 inclusions were only partially refilled by the low-salinity FLUID-2, giving the intermediate salinities recorded in Cal4 (Fig. 8D). Conversely, Cal5 spatic rhombohedra only record the lowsalinity FIs suggesting that this phase precipitated from pure FLUID-2 without involving the re-opening of older veins.

\section{Stage 3}

This is recorded by the veins of GROUP-3 from Solforate, precipitated from a cooler ( Th mode is $90-95^{\circ} \mathrm{C}$ ) and moderately saline aqueous fluid (4.3-6.2 wt $\% \mathrm{NaCl}$ eq.) carrying $\mathrm{CO}_{2}$. The latter statement is suggested by the supposed presence, in some FIs, of clathrate phases melting last (Table 1) and by the association of the vein calcite from the same locality with dawsonite (Fabbrini 2010). Therefore, the fluid system named FLUID-3, although characterized by different conditions than FLUID-2, was possibly related to the fossil hydrothermalism of the area involving meteoric fluids.

\section{SYNOPSIS}

The FI temperature information from the different calcites, combined with their oxygen isotope composition, allowed to characterize the isotope composition of the parent fluids (Fig. 11) using the water-calcite fractionation equation after Friedman \& O’Neil (1977). 


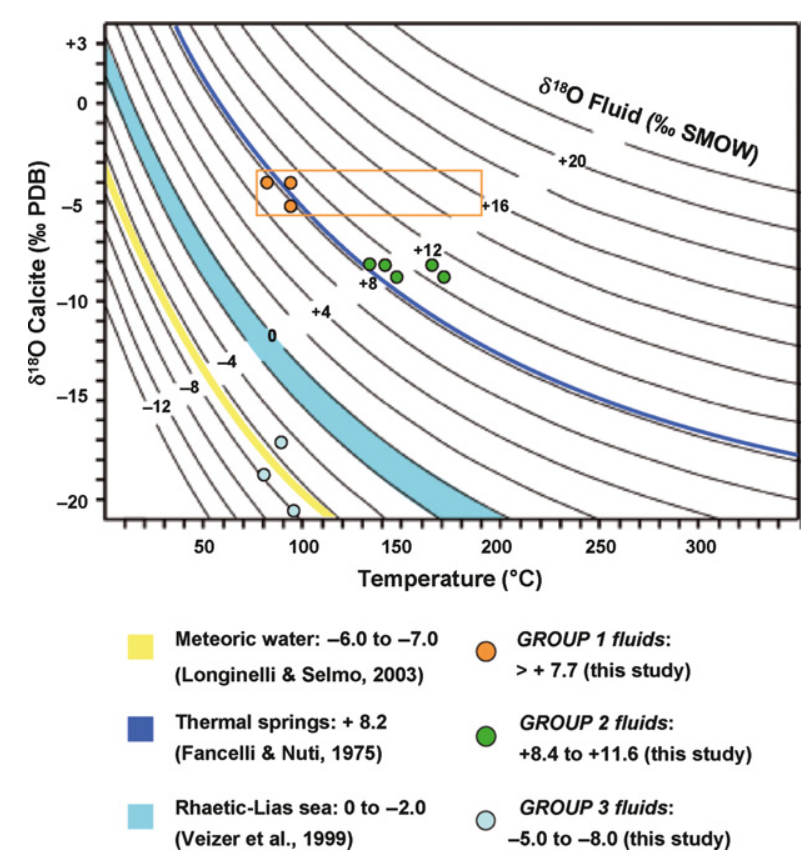

Fig. 11. Homogenization temperatures versus $\delta^{18} \mathrm{O}$ values for the calcite veins from the Poggio Zoccolino area related to the burial syn-tectonic fluid system (GROUP-1) and late hydrothermal $\mathrm{CO}_{2}$-bearing fluid system (GROUP-2). The $\delta^{18} \mathrm{O}$ composition of the fluid in equilibrium with calcite as function of the temperature was calculated using the fractionation equation of Friedman \& O'Neil (1977). The temperatures for the GROUP-2 fluid (FLUID-2) were not corrected for pressure assuming a shallow depth for the hydrothermal system. For GROUP-1 fluid (FLUID-1), the lower range of homogenization temperatures was taken, and the maximum pressure correction is reported (orange box). The composition of the fluids from the present-day hydrothermal sources (Fancelli \& Nuti 1975), of Late Triassic to Early Jurassic seawater (Veizer et al. 1999) and of rain waters from southern Tuscany (Longinelli \& Selmo 2003) is also reported. For comparison, the fluid composition of hydrothermal calcites from the Solforate locality is reported as well (GROUP-3 fluid).

For GROUP-1 veins and correspondent FLUID-1, because of the thermal re-equilibration process having affected the FIs during the regional metamorphism of the Apennines orogenesis, the lower range of the measured homogenization temperatures $\left(110-120^{\circ} \mathrm{C}\right)$ was taken as the closest approximation of real Th values, prior to reequilibration. The $\delta^{18} \mathrm{O}$ for FLUID-1 results to be between 7.7 and 8.5 SMOW (Fig. 11). These are only minimum values, and considerations on the maximum pressure correction are necessary. The maximum burial reached by the Tuscan Nappe carbonate succession during basin formation and later collisional phase is not well constrained. However, it can be argued that the Tuscan Nappe during basinal stage reached a minimum depth of $300 \mathrm{~m}$ (evidences of bedding parallel stylolites) and a maximum depth of 1000 $\mathrm{m}$ (maximum thickness of the pre-Late Oligocene succession, that is, deposited before the stacking of the Tuscan Nappe in the orogenic belt). During the compressional events involving the Tuscan Nappe in the northern
Apennines belt (Late Oligocene - Early Miocene), temperatures of $200 \pm 50^{\circ} \mathrm{C}$ were reached (Franceschelli et al. 1994; Battaglia et al. 2007). By taking the temperature of $250^{\circ} \mathrm{C}$ and considering an underestimated geothermal gradient of $30^{\circ} \mathrm{C} / \mathrm{km}$ (and assuming the gradient constant during the tectonic stacking), an overestimated maximum depth of $8 \mathrm{~km}$ can be deduced for the Tuscan Nappe. Isochores were constructed for the FIs of GROUP-1 veins using the minimum Th range of $110-120^{\circ} \mathrm{C}$, a fluid density from salinity mode values (see Table 1) and lithostatic pressure conditions. The maximum possible temperatures obtained from the intersections between isochores and $\mathrm{P}_{\max }$ line (for a depth of $8 \mathrm{~km}$ ) are used to depict all possible FLUID-1 compositions (orange box in Fig. 11). Although a precise estimation of the fluid $\delta^{18} \mathrm{O}$ is not possible, it results that FLUID-1 had a moderately to extremely heavy $\delta^{18} \mathrm{O}$ composition, likely explained by the long-lasting water/rock interaction among pore fluids and Tuscan Nappe rocks during burial diagenesis. An important contribution of ${ }^{18} \mathrm{O}$ to the pore fluids could have come from the Burano Fm sulphates, which are more prone to dissolution, rather than from the more carbonatic formations.

Considering that the parent fluids for GROUP-2 and GROUP-3 veins derived from a shallow hydrothermal system, the measured homogenization temperatures well approximate the true FI trapping conditions (the pressure correction to be applied is minor). It results that GROUP-2 vein calcites formed from FLUID-2 with $\delta^{18} \mathrm{O}$ of 8.4 to 11.6 SMOW, whereas GROUP-3 vein calcites precipitated from FLUID- 3 with $\delta^{18} \mathrm{O}$ of -5 to -8 SMOW.

These $\delta^{18} \mathrm{O}$ values have been compared with the possible sources of fluids from the study area (Fig. 11). Present-day fluids from the hydrothermal reservoir have $\delta^{18} \mathrm{O}$ of 8.2 SMOW (Fancelli \& Nuti 1975). Conversely, present-day rain water in southern Tuscany is characterized by $\delta^{18} \mathrm{O}$ of -6.0 to -7.0 (Longinelli \& Selmo 2003). It results that FLUID-2 was strongly enriched in ${ }^{18} \mathrm{O}$ compared with the meteoric fluids. It was also isotopically heavier than the present-day fluids emerging from the Bagni San Filippo reservoir. Such high $\delta^{18} \mathrm{O}$ values could recall those of hydrothermal fluids partially derived from magmatic systems (Sheppard 1986). D'Amore \& Bolognesi (1994) invoked a magmatic fluid contribution to the hydrothermal fluids from the shallow geothermal fields of Larderello (southern Tuscany), in order to explain the high $\delta^{18} \mathrm{O}$ values (in the range of 11-15 SMOW), which deviated from the most commonly recorded values overlapping the meteoric water line. Liotta et al. (2009) investigated calcite veins from the Boccheggiano-Montieri geothermal area (southern Tuscany), and although favouring a different hypothesis, they do not exclude a mixing between meteoric and magmatic fluids for the samples with higher $\delta^{18} \mathrm{O}$. A minor input of magmatic-derived fluid to the fossil hydrothermal system of Bagni San Filippo cannot be ruled out, 
although it is not supported by several evidences: (i) hypersaline multiphase FIs, which typically accompany magmatic-derived fluids (Roedder 1984; Hedenquist 1995), were not recorded in the studied GROUP-2 veins; (ii) cements precipitated from magmatic-derived fluids (i.e. with strong influence of mantle derived $\mathrm{CO}_{2}$ ) display characteristically low $\delta^{13} \mathrm{C}$ (down to -7 ; e.g. Horton et al. 2012) as $\delta^{13} \mathrm{C}$ values of magmatic $\mathrm{CO}_{2}$ typically range between -7.5 and -5.5 (Galimov 1968; Fuex \& Baker 1973). The slightly lower $\delta^{13} \mathrm{C}$ of FLUID-2 compared with FLUID-1 is more likely justified by the ingress of meteoric fluids in the system; and (iii) The low-salinity recorded in minerals precipitated from deep geothermal reservoirs of the Monte Amiata (Ruggieri et al. 2004; Giolito 2005) and in present-day deep fluids (Batini et al. 2003 ) does not suggest either a contribution of magmaticderived fluids.

The strong enrichment in ${ }^{18} \mathrm{O}$ for FLUID-2 was more likely linked to an effective interaction with ${ }^{18} \mathrm{O}$-rich carbonatic and siliciclastic rocks from the reservoir. Accordingly, the present-day hydrothermal fluids from Bagni San Filippo possibly reflect a less effective interaction with such ${ }^{18} \mathrm{O}$ rich sediments. Fluid/rock re-equilibration mainly depends on fluid temperature and time of interaction. Present-day fluids from the shallow reservoir have temperatures of 60 $80^{\circ} \mathrm{C}$ (Chiodini et al. 1995), that is, fairly lower than those attributed to FLUID-2 (Fig. 8C and Table 1). A slow fluid circulation, as for poorly permeable rocks, could have provided long interaction times, whereas deeper circuits for the past hydrothermal system would have provided both higher temperatures and longer time for interaction. However, also a lower rain water supply to the past system, controlled by local to global climatic changes, could have caused stronger interaction between fluids and reservoir rocks, justifying a similar effect. A combination of these three factors (tighter fractured reservoir, longer/deeper circuits and reduced meteoric recharge) could explain the heavy $\delta^{18} \mathrm{O}$ of the past hydrothermal FLUID-2.

FLUID-3 from GROUP-3 calcite veins has a typically meteoric signature (Fig. 11), similar to the one reported from other shallow geothermal systems of southern Tuscany (Liotta et al. 2009; Rossetti et al. 2011). The meteoric signature of FLUID-3 could indicate a system where circulation was fast (no time for the fluid to re-equilibrate with reservoir rocks), possibly related to more permeable lithologies. Furthermore, the lower temperatures of FLUID-3 (compare Fig. 8C,E) could have accounted for weaker interactions with the hosts.

\section{INTERACTIONS WITH THE VEIN HOST ROCKS}

Geochemical analysis indicate that the Tuscan Nappe succession from Monte Cetona (Fig. 1) reflects typical marine sedimentation and early cementation only slightly affected by recrystallization and water-rock interaction during burial diagenesis (Fig. 9). The samples from Poggio Zoccolino (Fig. 1) plot in two distinct clouds, corresponding to GROUP-1 and GROUP-2 calcite veins and relative host rocks (Fig. 10), with a good overlap between the two groups of veins-hosts, suggesting equilibrium among them. In particular, GROUP-1 samples, which carry $\delta^{13} \mathrm{C}$ typically inherited from marine carbon, display $\delta^{18} \mathrm{O}$ and ${ }^{87} \mathrm{Sr} /{ }^{86} \mathrm{Sr}$ slightly different from marine Late Triassic to Early Jurassic seawater (Fig. 10). This trend is comparable with the one observed in the Monte Cetona lithologies sampled away from any obvious past fluid circulation (no large veins in the close vicinity of the samples), although in Poggio Zoccolino, the shift towards lower $\delta^{18} \mathrm{O}$ and more radiogenic ${ }^{87} \mathrm{Sr} /{ }^{86} \mathrm{Sr}$ is greater. The Poggio Zoccolino GROUP-1 samples result to be isotopically similar to diagenetically altered carbonates of the Tuscan Nappe (Cortecci \& Lupi 1994) from areas not expected to have interacted with hydrothermal fluids but which underwent the collisional events of northern Apennines emplacement, accounting for low-to-middle anchimetamorphic conditions (Cerrina Feroni et al. 1983). The minor resetting due to water-rock interaction processes recorded by the Tuscan Nappe succession from Monte Cetona could be explained by the actual lack of burial syn-tectonic calcite veins in this area compared with Poggio Zoccolino. Accordingly, the parent fluids of GROUP-1 veins would have interacted with the host rocks of Poggio Zoccolino to cause their stronger geochemical resetting.

GROUP-2 samples (both veins and hosts) display a fairly different geochemical signature of most parameters compared with the other carbonates (see Figs 9 and 10), suggesting that they were related to a different fluid system. This is in agreement with the fluid history reconstruction (see previous sections), pointing to a burial Late Oligocene to Early Miocene syn-tectonic fluid system for GROUP-1 samples and to a more recent (possibly Pleistocene) hydrothermal fluid system for GROUP-2 samples. The Tuscan Nappe rocks from Poggio Zoccolino close to GROUP-2 calcite veins underwent a clear isotopic resetting (Fig. 10). A similar trend is recorded by the distribution of some minor and trace elements: GROUP-2 calcites and correspondent hosts seem to be enriched in $\mathrm{Fe}, \mathrm{Mn}, \mathrm{Sr}, \mathrm{Ba}$ and Ni compared with GROUP-1 samples. These bulk elemental analyses may be regarded as potential indicators of geochemical trends and seem to corroborate the hypothesis that the composition of the carbonates hosting the veins is dependent on the fluid system they have interacted with.

GROUP-1 and GROUP-2 veins may coexist in some of the Poggio Zoccolino outcrops. The preservation of the burial diagenetic signature in the host rocks of GROUP-1 veins suggests that they did not fully re-equilibrate with the later hydrothermal fluids. Water-rock interaction pro- 


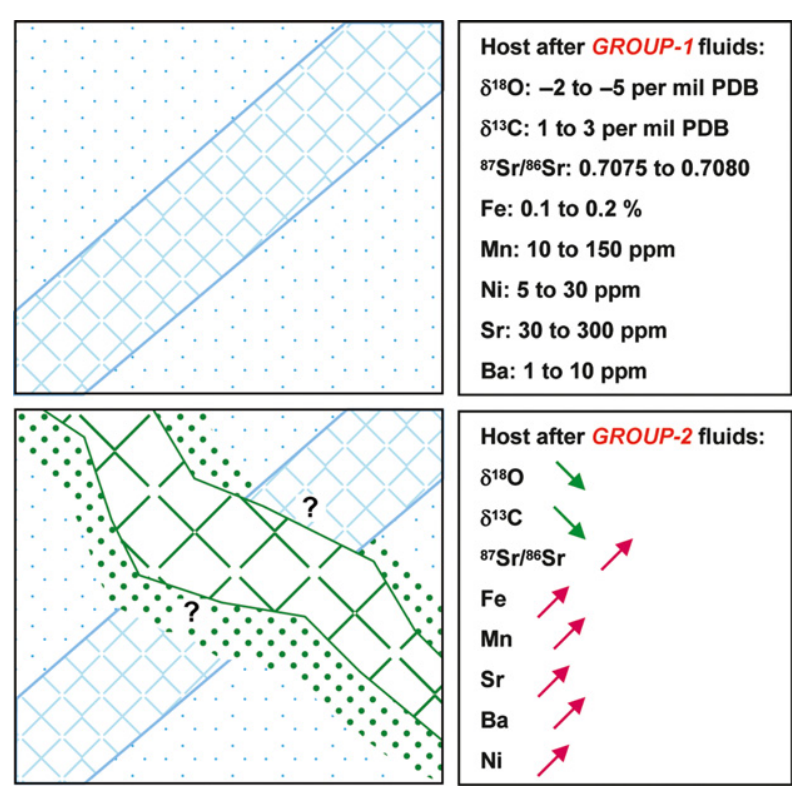

Fig. 12. Schematic evolution of the Tuscan Nappe lithologies hosting the two main groups of fractures recorded in the Poggio Zoccolino hydrothermal area. The upper sketch refers to the hosts of GROUP-1 veins; on the side, the host geochemical signature is summarized. The lower sketch refers to the hosts of GROUP-2 veins; on the side, the red and green arrows indicate, respectively, an increase or a decrease in the different geochemical parameters.

cesses governed by the circulation of the $\mathrm{CO}_{2}$-rich FLUID-2 were thus restricted to the GROUP-2 fracture vicinity (few $\mathrm{cm}$ or less). The occurrence of the already discussed geochemical resetting within the Tuscan Nappe sediments is therefore dependent on their distance from GROUP-2 veins (Fig. 12). Irrespectively from the lateral extension of the resetting processes away from fractures, it is clear that some portions of the host rocks re-equilibrated with $\mathrm{CO}_{2}$-rich fluids in the past. As a consequence, textural and mineralogical modifications of the rock matrix are expected to have occurred, compared with the undisturbed succession from areas never affected by hydrothermalism. In this respect, the rocks of the Tuscan Nappe may serve as analogue for understanding the diagenesis provoked by $\mathrm{CO}_{2}$-rich fluids on such carbonate-dominated reservoirs, to feed geochemical models addressed to the prediction of modifications induced by anthropogenic geological storage.

Through this study, it has been demonstrated that some of the investigated fractures from Poggio Zoccolino enabled past hydrothermal $\mathrm{CO}_{2}$-rich fluids to migrate out of the reservoir (and especially through the Calcare Massiccio Fm). The geochemical modifications documented on the sediments close to the hydrothermal $\mathrm{CO}_{2}$-related veins could be used to retrace the past hydrothermal flows elsewhere through the Tuscan Nappe reservoirs and potentially become a tool to discriminate hydrothermally altered rocks from undisturbed ones.
Interaction with $\mathrm{CO}_{2}$-charged fluids may be accompanied by intense carbonate dissolution (Watson et al. 2004a and b; May 2005), although this is not an ubiquitous feature (Haszeldine et al. 2005). Matrix porosity increase or grains corrosion were not observed in the Calcare Massiccio Fm recording most hydrothermal veins. Evidences from analogues and modelling suggest that it may take hundreds of thousands of years for reservoirs to fully react with $\mathrm{CO}_{2}$ (e.g. Gaus et al. 2004; Wilkinson et al. 2009), explaining the occurrence of this 'inert' behaviour. Furthermore, the studied rocks were quite tight after compaction and early cementation and circulation of hydrothermal fluids occurred mostly through fractures with low-activity surface for interaction. However, in subsurface exploration plays of the Amiata area, the Burano Fm, which underlies the Calcare Massiccio Fm, hosting most hydrothermal calcite veins, may exhibit an important secondary porosity. Dissolution could have been focussed on this basal formation, which was dominantly constituted by more soluble sulphates, although the hypothesis cannot be proved with the available data.

\section{MAIN FEATURES OF THE BAGNI SAN FILIPPO FOSSIL SYSTEM}

The results of this study indicated that the past hydrothermal system of Bagni San Filippo was fed by meteoric waters mixed with $\mathrm{CO}_{2}$ of deep origin, possibly raised through both strike-slip and normal faults, the latter developed in the releasing stepover zone (Brogi et al. 2010). The fluid was characterized by temperatures of about $165 \pm 35^{\circ} \mathrm{C}$, salinity mostly from 1.2 to $4.3 \mathrm{wt} \% \mathrm{NaCl}$ eq. and $\mathrm{CO}_{2}$ content between 0.15 and $0.34 \mathrm{wt} \%$; these data can be used to develop a geochemical model aimed to simulate the interaction of this $\mathrm{CO}_{2}$-rich fluid with the carbonate-dominated reservoir rocks.

The past hydrothermal system of Bagni San Filippo, in contrast with the system of FLUID-3 from Solforate, was characterized by relatively slow and/or deep flow circuits, which favoured advanced water-rock interaction. This suggests a compartmentalization of the shallow geothermal reservoirs from the area, in agreement with the fact that the reservoir rocks consist of isolated geological bodies (i.e. laterally segmented bodies related to the boudinage of the upper crust; Brogi 2008) sandwiched within low-permeability successions.

On the other hand, the past hydrothermal system of Bagni San Filippo shares similar features with the present shallow reservoir of the Bagnore geothermal field (Fig. 1). Indeed, this latter reservoir had initial temperature (i.e. before exploitation) estimated by Atkinson et al. (1978) of about $175^{\circ} \mathrm{C}$, thus similar to the $\mathrm{Th}$ mode $\left(165^{\circ} \mathrm{C}\right)$ of FLUID-2. The shallow reservoir of the Bagnore field was initially characterized by the presence of a gas cap, mainly 
composed by $\mathrm{CO}_{2}$ (up to $80 \%$ ) and steam, which overlaid an aqueous $\mathrm{CO}_{2}$-saturated liquid. Significant amount of $\mathrm{CO}_{2}$ was also found in FLUID-2. A further similarity arises from the fact that in the Bagnore shallow reservoir, the $\mathrm{CO}_{2}$ as well as the carbonate ionic species was in chemical equilibrium with the carbonate rocks (Atkinson et al. 1978). Similarly, a strong interaction between FLUID-2 and host rocks has been documented, this suggesting possible equilibrium.

In this view, it is suggested that the past hydrothermal system of Bagni S. Filippo represented an analogue of the present shallow geothermal system of Bagnore. These similarities could allow transposing available information from the Bagnore field (i.e. permeability and porosity of the reservoir rocks, etc.) to the Bagni San Filippo system, which are needed as input data to establish a fluid/rock interaction geochemical model for the studied reservoir rocks.

\section{CONCLUSIONS}

A new set of geochemical and fluid inclusion data on mineralized veins from the Monte Amiata geothermal region was produced to characterize past fluid circulations through the Tuscan Nappe succession, representing at depth the least explored reservoir of the area. The effects of water-rock interaction recorded by the different lithologies were also investigated.

Two main groups of veins were distinguished from Poggio Zoccolino, close to the shallow hydrothermal system of Bagni San Filippo, and two correspondent parent fluid systems were characterized: FLUID-1 precipitated syn-tectonic calcite veins in the burial diagenetic realm, whereas FLUID-2 was related to a fossil geothermal system, fed by low-salinity meteoric fluids, charged in $\mathrm{CO}_{2}$ of deep origin and enriched in ${ }^{18} \mathrm{O}$ and ${ }^{87} \mathrm{Sr}$ after interaction with the subsurface rocks. A third system, named FLUID-3, was recognized only in veins from the Ligurian Units cap rocks and records a meteoric signature similar to other shallow hydrothermal reservoirs of southern Tuscany. In this respect, the fossil hydrothermal system of Bagni San Filippo represents an exception in the so-far-documented fossil systems of the Amiata region, suggesting past compartmentalization in the shallow geothermal reservoir.

Comparison of FLUID-2 with the fluid from the present-day hydrothermal system of Bagni San Filippo suggests that the reservoir fluids were hotter and water-rock interaction was more effective during FLUID-2 circulation. Both deeper circulation circuits and lower permeable lithologies in the past hydrothermal system could be invoked. However, climatic changes, lowering the rain water supply to the geothermal system, could have induced a similar effect.

The host rocks having interacted with the hydrothermal and $\mathrm{CO}_{2}$-bearing FLUID-2 display a strong geochemical reset not documented elsewhere. Such feature could be used to differentiate in other locations the rocks having interacted with the hydrothermal fluids from the undisturbed ones. The extension of the phenomenon was limited to a few centimetres away from the vein-host contact. In these portions, mineralogical and textural modifications of the host rock matrix are likely to have occurred.

\section{ACKNOWLEDGEMENTS}

We are thankful to G. Chiodini (INGV OV, Italy) for promoting the original development of the survey. O. Vincké and T. Parra (IFP EN) are thanked for their further support. We are grateful to $\mathrm{H}$. Ravelojaona (IFP EN) for assistance during field sampling and preparing most thin sections. M. Joachimski (GeoZentrum Nordbayern, Germany) and R. Ellam (SUERC, UK) are thanked for allowing most analysis of $\mathrm{O}-\mathrm{C}$ and $\mathrm{Sr}$ isotopes, respectively. Two anonymous referees are aknowledged for their constructive comments and suggestions.

\section{REFERENCES}

Armannsson $\mathrm{H}$ (2003) $\mathrm{CO}_{2}$ emissions from geothermal plants. International geothermal conference, Reykjavik September 2003, Paper 103, 56-62.

Armitage PJ, Worden RH, Faulkner DR, Aplin AC, Butcher AR, Iliffe J (2010) Diagenetic and sedimentary controls on porosity in Lower Carboniferous fine-grained lithologies, Krechba field, Algeria: a petrological study of a caprock to a carbon capture site. Marine and Petroleum Geology, 27, 1395-410.

Assayag N, Matter J, Ader M, Goldberg D, Agrinier P (2009) Water-rock interactions during a $\mathrm{CO}_{2}$ injection field-test: implications on host-rock dissolution and alteration effects. Chemical Geology, 265, 227-35.

Atkinson P, Celati R, Corsi R, Kucuk F, Ramey HJ Jr (1978) Thermodynamic behaviour of the Bagnore geothermal field. Geothermics, 7, 185-208.

Baines SJ, Worden RH (2004) The long-term fate of $\mathrm{CO}_{2}$ in the subsurface: natural analogues for $\mathrm{CO}_{2}$ storage. In: Geological Storage of Carbon Dioxide (eds Baines SJ, Worden RH). Geological Society of London, Special Publications, 233, 59-85.

Baldi P, Bertini G, Ceccarelli A (1993) Geothermal fields of Central Italy. Resource Geology, Special Issue, 16, 69-81.

Bambini AM, Brogi A, Cornamusini G, Costantini A, Foresi LM, Lazzaroto A (2010) Geologia dell'area di Rapolano Terme in Provincia di Siena (Appennino Settentrionale). Italian Journal of Geosciences, 129, 457-95.

Barbier E (2002) Geothermal energy technology and current status: an overview. Renewable and Sustainable Energy Reviews, 6, 3-65.

Barelli A, Ceccarelli A, Dini I, Fiordelisi A, Giorgi N, Lovari F, Romagnoli P (2010) A review of the Mt. Amiata geothermal system (Italy). Proceedings World Geothermal Congress, 2010, 1-4.

Batini F, Brogi A, Lazzarotto A, Liotta D, Pandeli E (2003) Geological features of the Larderello-Travale and Monte Amiata geothermal areas (southern Tuscany, Italy). Episodes, 26, 239-44.

Battaglia S, Gherardi F, Gianelli G, Leoni L, Origlia F (2007) Clay mineral reactions in an active geothermal area (Mt. Amiata, southern Tuscany, Italy). Clay Minerals, 42, 353-72. 
Beitler B, Parry WT, Chan MA (2005) Fingerprints of fluid flow: chemical history of the Jurassic Navajo sandstone, southern Utah, USA. Journal of Sedimentary Research, 75, 547-61.

Belkin H, De Vivo B, Gianelli G, Lattanzi P (1985) Fluid inclusions in minerals from the geothermal fields of Tuscany, Italy. Geothermics, 14, 59-72.

Bertini G, Cappetti G, Dini I, Lovari F (1995) Deep drilling results and updating of geothermal knowledge on the Monte Amiata area. Proceedings of the World Geothermal Congress, Florence, Italy 2, 1283-6.

Bodnar RJ (1993) Revised equation and table for determining the freezing point depression of $\mathrm{H}_{2} \mathrm{O}-\mathrm{NaCl}$ solutions. Geochimica et Cosmochimica Acta, 57, 683-4.

Brogi A (2004) Miocene low-angle detachments and upper crustal megaboudinage in the Monte Amiata geothermal area (Northern Apennines, Italy). Geodinamica Acta, 17, 375-87.

Brogi A (2006) Evolution, formation mechanism and kinematics of a contractional shallow shear zone within sedimentary rocks of the Northern Apennines (Italy). Eclogae Geologicae Helvetiae, 99, 29-47, doi:10.1007/s00015-006-1174-0.

Brogi A (2008) The structure of the Monte Amiata volcanogeothermal area (Northern Apennines, Italy): NeogeneQuaternary compression versus extensions. International Journal of Earth Sciences, 97, 677-703.

Brogi A, Liotta D, Meccheri M, Fabbrini L (2010) Transtensional shear zones controlling volcanic eruptions: the Middle Pleistocene Monte Amiata volcano (inner Northern Apennines, Italy). Terra Nova, 22, 137-46.

Brogi A, Fabbrini L, Liotta D (2011) Sb-Hg ore deposit distribution controlled by brittle structures: the case of the Selvena mining district (Monte Amiata, Tuscany, Italy). Ore Geology Reviews, 41, 35-48.

Brosse E, Bildstein O, Swennen R (2005) Gas-water-rock interactions induced by reservoir exploration, $\mathrm{CO}_{2}$ sequestration, and other geological storage. Oil \& Gas Science and Technology, 60, 9-18.

Brunet C, Monie P, Jolivet L, Cadet JP (2000) Migration of compression and extension in the Tyrrhenian sea, insights from ${ }^{40} \mathrm{Ar} /{ }^{39} \mathrm{Ar}$ ages on micas along a transect from Corsica to Tuscany. Tectonophysics, 321, 127-55.

Calamai A, Cataldi R, Squarci P, Taffi L (1970) Geology, geophysics and hydrogeology of the Monte Amiata geothermal fields. Geothermics, Special Issue 1 (maps and comments), 1-9.

Carmignani L, Decandia FA, Disperati L, Fantozzi PL, Lazzarotto A, Liotta D, Meccheri M (1994) Tertiary extensional tectonics in Tuscany (Northern Apennines, Italy). Tectonophysics, 238, 295-315.

Cerrina Feroni A, Plesi G, Fanelli G, Leoni G, Martinelli P (1983) Contributo alla conoscenza dei processi metamorfici di grado molto basso (anchimetamorfismo) a carico della Falda Toscana nell'area del ricoprimento apuano. Bollettino della Società Geologica Italiana, 102, 269-80.

Chiodini G, Frondini F, Marini L (1995) Theoretical geothermometers and $\mathrm{PCO}_{2}$ indicators for aqueous solutions coming from hydrothermal systems of medium-low temperature hosted in carbonate-evaporite rocks. Application to the thermal springs of the Etruscan Swell, Italy. Applied Geochemistry, 10, $337-46$.

Chiodini G, Cardellini C, Amato A, Boschi E, Caliro S, Frondini F, Ventura G (2004) Carbon dioxide Earth degassing and seismogenesis in central and southern Italy. Geophysical Research Letters, 31, L07615, doi:10.1029/2004GL019480.

Chiodini G, Caliro S, Cardellini C, Avino R, Granieri D, Schmidt A (2008) Carbon isotopic composition of soil $\mathrm{CO}_{2}$ efflux, a powerful method to discriminate different sources feeding soil
$\mathrm{CO}_{2}$ degassing in volcanic-hydrothermal areas. Earth and Planetary Science Letters, 274, 372-9.

Cortecci G, Lupi L (1994) Carbon, oxygen and strontium isotope geochemistry of carbonates rocks from the Tuscan Nappe, Italy. Mineralogica et petrographica acta, XXXVII, 63-80.

Czernichowski-Lauriol I, Rochelle C, Gaus I, Azaroual M, Pearce J, Durst P (2006) Geochemical interactions between $\mathrm{CO}_{2}$, pore-waters and reservoir-rocks. In: Advances in the Geological Storage of Carbon Dioxide (eds Lombardi S, Altunina LK, Beaubien SE). NATO Science Series. IV. Earth and Environmental Sciences, 65, 167-74.

D'Amore F, Bolognesi L (1994) Isotopic evidence for a magmatic contribution to fluids of the geothermal systems of Larderello, Italy, and the Geysers, California. Geothermics, 23, 21-32.

Dini A, Gianelli G, Puxeddu M, Ruggieri G (2005) Origin and evolution of Pliocene-Pleistocene granites from the Larderello geothermal field (Tuscan Magmatic Province Italy). Lithos, 81, $1-31$.

Donnini M, Chiodini G, Avino R, Baldini A, Cardellini C, Caliro S, Frondini F, Granieri D, Morgantini N (2007) Carbon dioxide degassing at Bagni San Filippo (Tuscany, Italy): quantification and modeling of gas release. Geophysical Research Abstracts, 9, 02954, SRef-ID: 1607-7962/gra/EGU2007-A02954.

Elter FM, Pandeli E (1991) Structural features of the metamorphic Paleozoic-Triassic sequences in deep geothermal drillings of the Monte Amiata area (SE Tuscany, Italy). Bollettino Società Geologica Italiana, 110, 511-22.

Emberley S, Hutcheon I, Shevalier M, Durocher K, Mayer B, Gunter WD, Perkins EH (2005) Monitoring of fluid-rock interaction and $\mathrm{CO}_{2}$ storage through produced fluid sampling in the Weyburn $\mathrm{CO}_{2}$-injection enhanced oil recovery site, Saskatchewan, Canada. Applied Geochemistry, 20, 1131-57.

Fabbrini L (2010) Relazioni tra strutture e circolazione dei fluidi idrotermali: il sistema geotermico fossile attuale nell'area del Monte Amiata. PhD thesis, Università di Siena (Italy), 180 p. (unpublished).

Fancelli R, Nuti S (1975) Studio sulle acque geotermiche e minerali della parte orientale della provincia di Siena. Bollettino della Società Geologica Italiana, 94, 135-55.

Faure G (1986) Principles of Isotope Geology, 2nd edn, p. 589. John Wiley and Sons, New York.

Ferrari L, Conticelli S, Burlamacchi L, Manetti P (1996) Volcanological evolution of the Monte Amiata, southern Tuscany: new geological and petrochemical data. Acta Vulcanologica, 8, 41-56.

Franceschelli M, Pandeli E, Puxeddu M, Porcu R, Fadda S (1994) Illite crystallinity in pelitic and marly rocks from the Northern Apennines (southern Tuscany and Umbria, Italy). Newes Jahrbuch für Mineralogie Mh., 8, 367-84.

Frezzotti ML, Tecce F, Casagli A (2012) Raman spectroscopy for fluid inclusion analysis. Journal of Geochemical Exploration, 112, $1-20$.

Friedman I, O’Neil JR (1977) Compilation of stable isotope fractionation factors of geochemical interest. In: Data of Geochemistry (ed Fleischer M). US Geological Survey Professional Paper, 440, 1-12.

Frondini F, Caliro S, Cardellini C, Chiodini G, Morgantini N (2009) Carbon dioxide degassing and thermal energy release in the Monte Amiata volcanic-geothermal area (Italy). Applied Geochemistry, 24, 860-75.

Fuex AN, Baker DR (1973) Stable carbon isotopes in selected granitic, mafic, and ultramafic igneous rocks. Geochimica et Cosmochimica Acta, 37, 2509-21. 
Galimov EM (1968) Geochemistry of Carbon Stable Isotopes, 224 p Nedra, Moscow, Russia.

Gaus I, Le Guern C, Pearce J, Pauwels H, Shepherd T, Hatziyannis G, Metaxas A (2004) Comparison of long-term geochemical interactions at two natural $\mathrm{CO}_{2}$-analogues: Montmiral (Southeast Basin, France) and Messokampos (Florina Basin, Greece) case studies. Proceedings of the 7th International Conference on Greenhouse Gas Control Technologies, Vancouver (Canada), 1, 561-9.

Gianelli G, Puxeddu M, Batini F, Bertini G, Dini I, Pandeli E, Nicolich R (1988) Geological model of a young volcanoplutonic system: the geothermal region of Monte Amiata (Tuscany, Italy). Geothermics, 17, 719-34.

Gianelli G, Ruggieri G, Mussi M (1997a) Isotopic and fluid inclusion study of hydrothermal and metamorphic carbonates in the Larderello geothermal field and surrounding areas, Italy. Geothermics, 26, 393-417.

Gianelli G, Manzella A, Puxeddu M (1997b) Crustal models of the geothermal areas of southern Tuscany (Italy). Tectonophysics, 281, 221-39.

Giolito C (2005) Geochemical evolution of the crustal fluids in the hydrothermal system of Mt. Amiata (Central Italy). PhD thesis, Università di Firenze (Italy), 184 p. (unpublished).

Haszeldine RS, Quinn O, England G, Wilkinson M, Shipton ZK, Evans JP, Heath J, Crossey L, Ballentine CJ, Graham CM (2005) Natural geochemical analogues for carbon dioxide storage in deep geological porous reservoirs, a United Kingdom perspective. Oil \& Gas Science and Technology, 60, 33-49.

Hedenquist JW (1995) The ascent of magmatic fluid: discharge versus mineralization. In:Magmas, Fluids, and ore Deposits (edThompson JFH), pp. 263-89. Mineralogical Association of Canada Short Course Series, Victoria, British Columbia, 23.

Hellevang H, Declercq J, Aagaard P (2011) Why is dawsonite absent in $\mathrm{CO}_{2}$ charged reservoirs? Oil of Gas Science and Technology, 66, 119-35.

Henley RW, Ellis AJ (1983) Geothermal systems ancient and modern: a geochemical review. Earth-Science Reviews, 19, 1-50.

Horton TW, Atkinson L, Oze C (2012) Hydrothermal Carbonate Geochemistry of the Ngatamariki Subsurface Reservoir New Zealand, pp. 1-8. Proceedings of the Thirty-Seventh Workshop on Geothermal Reservoir Engineering, Stanford, California.

IEA GHG (2005) A review of natural $\mathrm{CO}_{2}$ occurrences and release and their relevance to $\mathrm{CO}_{2}$ storage. IEA Greenhouse Gas R\&D program. Report No. 2005/8, 95 p.

Johnson JW, Nitao JJ, Steefal CI, Knauss KG (2004) Reactive transport modeling of $\mathrm{CO}_{2}$ storage in saline aquifers to elucidate fundamental processes, trapping mechanisms and sequestration partitioning. In: Geological Storage of Carbon Dioxide (eds Baines SJ, Worden RH). Geological Society of London, Special Publications, 233, 107-28.

Kalin O, Patacca E, Renz O (1979) Jurassic pelagic deposits from Southeastern Tuscany; aspects of sedimentation and new biostratigraphic data. Ecologae Geologica Helvetica, 72, 715-62.

Kervevan C, Azaroual M, Durst P (2005) Improvement of the calculation accuracy of acid gas solubility in deep reservoir brines: application to the geological storage of $\mathrm{CO}_{2}$. Oil \& Gas Science and Technology, 60, 357-79.

Kharaka YK, Cole DR, Hovorka SD, Gunter WD, Knauss KG, Freifeld BM (2006) Gas-water-rock interactions in Frio formation following $\mathrm{CO}_{2}$ injection: implication for the storage of greenhouse gases in sedimentary basins. Geology, 34, 577-80.

Kim ST, Mucci A, Taylor BE (2007) Phosphoric acid fractionation factors for calcite and aragonite between 25 and $75^{\circ} \mathrm{C}$. Revisited. Chemical Geology, 246, 135-46.
Land LS (1980) The isotopic and trace element geochemistry of dolomite: the state of the art. In: Concepts and Models of Dolomitization (eds Zenger DH, Dunham JB, Ethington RL) Society for Sedimentary Geology, Special Publication, 28, 87110.

Lattanzi P (1999) Epithermal precious metal deposits of Italy - an overview. Mineralium Deposita, 34, 630-8.

Liotta D, Ruggieri G, Brogi A, Fulignati P, Dini A, Nardini I (2009) Migration of geothermal fluids in extensional terrains: the ore deposits of the Boccheggiano-Montieri area (Southern Tuscany, Italy). International Journal of Earth Sciences (Geologische Rundschau), 99, 623-44.

Longinelli A, Selmo E (2003) Isotopic composition of precipitation in Italy: a first overall map. Journal of Hydrology, 270, 75-88.

Lu J (2009) Natural Analogues of Carbon Dioxide Geological Storage. Interaction with Reservoir and Seal at Miller Field, UK North Sea, p. 177. VDM Verlag Dr. Müller, Saarbrücken.

Lu J, Wilkinson M, Haszeldine RS, Fallick AE (2009) Long-term performance of a mudrock seal in natural $\mathrm{CO}_{2}$ storage. Geology, $37,35-9$.

Luquot L, Gouze P (2009) Experimental determination of porosity and permeability changes by injection of $\mathrm{CO}_{2}$ into carbonate rocks. Chemical Geology, 265, 148-59.

May F (2005) Alteration of wall rocks by $\mathrm{CO}_{2}$-rich water ascending in fault zones: natural analogues for reactions induced by $\mathrm{CO}_{2}$ migrating along faults in siliciclastic reservoir and cap rocks. Oil \& Gas Science and Technology, 60, 9-18.

Minissale A (2004) Origin, transport and discharge of $\mathrm{CO}_{2}$ in Central Italy. Earth-Science Reviews, 66, 89-141.

Minissale A, Magro G, Vaselli O, Verrucchi C, Perticone I (1997) Geochemistry of water and gas discharges from the Mt. Amiata silicic complex and surrounding areas (central Italy). Journal of Volcanology and Geothermal research, 79, 223-51.

Molli G (2008) Northern Apennine-Corsica orogenic system: an updated overview. Geological Society of London, Special Publications, 298, 413-42.

Moore J, Adams M, Allis R, Lutz S, Rauzi S (2005) Mineralogical and geochemical consequences of the long-term presence of $\mathrm{CO}_{2}$ in natural reservoirs: an example from the SpringervilleSt.Jhons Field, Arizona, and New Mexico, U.S.A. Chemical Geology, 217, 365-85.

Pandeli E, Bertini G, Castellucci P, Morelli M (2005) The Ligurian, sub-Ligurian and Tuscan Units of the Monte Amiata geothermal region (South-eastern Tuscany): new stratigraphic and tectonic data. Bollettino della Società Geologica Italiana, Special Issue, 3, 55-71.

Passerini P (1964) Il Monte Cetona (provincia di Siena). Bollettino della Società Geologica Italiana, 83, 219-338.

Pauwels H, Gaus I, Le Nindre IM, Pearce J, CzernichowskiLauriol I (2007) Chemistry of fluids from a natural analogue for a geological $\mathrm{CO}_{2}$ storage site (Montmiral, France): lessons for $\mathrm{CO}_{2}$-water-rock interaction assessment and monitoring. Applied Geochemistry, 22, 2817-33.

Pearce JM, Czernichowski-Lauriol I, Lombardi S, Brune S, Nador A, Baker J, Pauwels H, Hatziyannis G, Beaubien S, Faber C (2003) A review of natural $\mathrm{CO}_{2}$ accumulations in Europe as analogues for geological sequestration. Geological Society of London, Special Publications, 233, 29-42.

Rochelle CA, Czernichowski-Lauriol I, Milodowski E (2004) The impact of chemical reactions on $\mathrm{CO} 2$ storage in geological formations: a brief review. In: Geological Storage of Carbon Dioxide. (eds Baines SJ, Worden RH). Geological Society of London, Special Publications, 233, 87-106. 
Roedder E (1984) Fluid inclusions. In: Reviews in Mineralogy (ed Ribbe P), Mineralogical Society of America, Washington, DC, $12,646 \mathrm{p}$.

Rosenbaum J, Sheppard SMF (1986) An isotopic study of siderites, dolomites and ankerites at high temperatures. Geochimica et Cosmochimica Acta, 50, 1147-50.

Rossetti F, Aldega L, Tecce F, Balsamo F, Billi A, Brilli M (2011) Fluid flow within damage zone of the Boccheggiano extensional fault (Larderello-Travale geothermal field, central Italy): structures, alteration and implications for hydrothermal mineralization in extensional settings. Geological Magazine, 148, 558-79.

Ruggieri G, Giolito C, Gianelli G, Manzella A, Boiron MC (2004) Application of fluid inclusions to the study of Bagnore geothermal field (Tuscany, Italy). Geothermics, 33, 675-92.

Sasada $\mathrm{M}$ (1985) $\mathrm{CO}_{2}$-bearing fluid inclusions from geothermal field. Geothermal Research Council Transactions, 9, 351-6.

Schacht U (2008) CO2-related Diagenesis in the Tuna Field, Gippsland Basin: A Natural Analogue Study for Geosequestration, pp. 485-8. Proceedings of PESA Eastern Australasian Basins Symposium III, Sydney (Australia).

Sheppard SMF (1986) Characterization and isotopic variations in natural waters. In: Stable Isotopes in High-temperature Geological Processes (eds Valley JW, Taylor HP Jr, O'Neil JR). Reviews in Mineralogy and Geochemistry, 16, 165-83.

Simmons SF, Browne PRL (1997) Saline fluid inclusions in sphalerite from the Broadlands Ohaaki geothermal system: a coincidental trapping of fluids being boiled toward dryness. Economic Geology, 92, 485-9.

Sterpenich J, Sausse J, Pironon J, Géhin A, Hubert G, Perfetti E, Grgic D (2009) Experimental ageing of oolitic limestones under
$\mathrm{CO}_{2}$ storage conditions. Petrophysical and chemical evidence. Chemical geology, 265, 99-112.

Veizer J, Ala D, Azmy K, Bruckschen P, Buhl D, Bruhn F, Carden GAF, Diener A, Ebneth S, Godderis Y, Jasper T, Korte C, Pawellek F, Podlaha OG, Strauss H (1999) ${ }^{87} \mathrm{Sr} /{ }^{86} \mathrm{Sr}, \delta^{13} \mathrm{C}$ and $\delta^{18} \mathrm{O}$ evolution of Phanerozoic seawater. Chemical Geology, $161,59-88$.

Watson M, Boreham CJ, Tingate PR (2004a) Carbon dioxide and carbonate cements in the Otway Basin: implications for geological storage of carbon dioxide. APPEA Journal, 44, 70320.

Watson M, Zwingmann N, Lemon NM (2004b) The Ladbroke Grove-Katnook carbon dioxide natural laboratory: a recent $\mathrm{CO}_{2}$ accumulation in a lithic sandstone reservoir. Energy, 29, 1457-66.

Wigand M, Carey JM, Schütt H, Spangenberg E, Erzinger J (2008) Geochemical effects of $\mathrm{CO}_{2}$ sequestration in sandstones under simulated in situ conditions of deep saline aquifers. Applied Geochemistry, 23, 2735-45.

Wilkinson M, Haszeldine RS, Fallick AE, Odling N, Stocker SJ, Gatliff RW (2009) $\mathrm{CO}_{2}$-mineral reaction in a natural sandstone analogue for $\mathrm{CO}_{2}$ storage - implication for modelling. Journal of Sedimentary Research, 79, 486-94.

Worden RH (2006) Dawsonite cement in the Triassic Lam Formation, Shabwa Basin, Yemen: a natural analogue for a potential mineral product of subsurface $\mathrm{CO}_{2}$ storage for greenhouse reduction. Marine and Petroleum Geology, 23, 61-77.

Xu TF, Apps JA, Pruess K (2003) Reactive geochemical transport simulation to study mineral trapping for $\mathrm{CO}_{2}$ disposal in deep arenaceous formations. Journal of Geophysical Research, 108, $1-4$. 


\title{
GEOFLUIDS
}

\author{
Volume 13, Number 2, May 2013 \\ ISSN 1468-8115
}

\section{CONTENTS}

99 EDITORIAL: 2012 Paris Geofluids VII Conference Summary \& Thematic Issue

Rudy Swennen, Francois Roure, Jacques Pironon, Fadi H. Nader and Mark Person

101 Synchrotron XRF and XANES investigation of uranium speciation and element distribution in fluid inclusions from unconformity-related uranium deposits

A. Richard, J. Cauzid, M. Cathelineau, M.-C. Boiron, J. Mercadier and M. Cuney

112 Age and genesis of the White Pine stratiform copper mineralization, northern Michigan, USA, from paleomagnetism

D.T.A. Symons, K. Kawasaki and J.F. Diehl

127 Modelling fault reactivation and fluid flow around a fault restraining step-over structure in the Laverton gold region, Yilgarn Craton, Western Australia

Y. Zhang, P.M. Schaubs, H.A. Sheldon, T. Poulet and A. Karrech

140 Fluid channeling along thrust zones: the Lagonegro case history, southern Apennines, Italy T. Gabellone, M. Gasparrini, A. Iannace, C. Invernizzi, S. Mazzoli and M. D'Antonio

159 Diagenesis versus hydrothermalism and fluid-rock interaction within the Tuscan Nappe of the Monte Amiata $\mathrm{CO}_{2}$-rich geothermal area (Italy)

M. Gasparrini, G. Ruggieri and A. Brogi

180 Diagenetic evolution of a fractured evaporite deposit (Vilobí Gypsum Unit, Miocene, NE Spain) M. Moragas, C. Martínez, V. Baqués, E. Playà, A. Travé, G. Alías and I. Cantarero

194 Geochemical simulations to assess the fluorine origin in Sierra de Gador groundwater (SE Spain) L. Daniele, M. Corbella, A. Vallejos, M. Díaz-Puga and A. Pulido-Bosch

204 Quantification of diagenesis impact on the reservoir properties of the Jurassic Arab $D$ and $C$ members (Offshore, U.A.E.)

F.H. Nader, E. De Boever, M. Gasparrini, M. Liberati, C. Dumont, A. Ceriani, S. Morad, O. Lerat and B. Doligez

221 Dedolomitization and reservoir quality: insights from reactive transport modelling L-.C. Escorcia, E. Gomez-Rivas, L. Daniele and M. Corbella

232 Reflux dolomitization of the Upper Permian Changxing Formation and the Lower Triassic Feixianguan Formation, NE Sichuan Basin, China L. Jiang, C.F. Cai, R.H. Worden, K.-K. Li and L. Xiang

246 Petroleum system evolution in the inverted Lower Saxony Basin, northwest Germany: a $3 D$ basin modeling study

B. Bruns, R. Di Primio, U. Berner and R. Littke 